\title{
STATISTICAL AND SIMULATION ANALYSIS OF HYDRAULIC-CONDUCTIVITY DATA FOR BEAR CREEK AND MELTON VALLEYS, OAK RIDGE RESERVATION, TENNESSEE
}

By Joseph F. Connell and Zelda Chapman Bailey

U.S. GEOLOGICAL SURVEY

Water-Resources Investigations Report 89-4062

Prepared in cooperation with the U.S. DEPARTMENT OF ENERGY

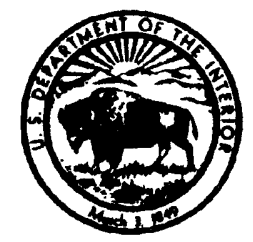




\title{
DEPARTMENT OF THE INTERIOR
}

\author{
MANUEL LUJAN, JR., Secretary \\ U.S. GEOLOGICAL SURVEY
}

Dallas L. Peck, Director

District Chief

U.S. Geological Survey

A-413 Federal Building

U.S. Courthouse

Nashville, Tennessee 37203
U.S. Geological Survey

Books and Open-File Reports

Box 25425

Federal Center, Bldg. 810

Denver, Colorado 80225 


\section{CONTENTS}

Abstract 1

Introduction $\mathbf{2}$

Purpose and scope of the report 2

Approach $\mathbf{2}$

Geologic setting 4

Hydraulic-conductivity data 4

Data sources 4

Data adjustments 7

Statistical analysis $\mathbf{8}$

Methods 8

Results of statistical tests $\mathbf{1 0}$

Grouping of hydraulic-conductivity data 12

Frequency analyses and quartile plots 14

Simulation analysis of hydraulic conductivity and ground-water flow 17

Application of ground-water flow and regression model to Bear Creek Valley

Description of model area 17

Assumptions 18

Model construction $\mathbf{1 8}$

Hydraulic conductivity 18

Water-table conditions $\quad \mathbf{1 8}$

Recharge and discharge 21

Coefficients of variation 22

Results of simulation $\mathbf{2 3}$

Model fit and conditioning $\mathbf{2 4}$

Model results and additional data needs $\mathbf{2 6}$

Sensitivity

29

Conclusions $\mathbf{3 2}$

References cited $\quad 37$

Appendix A 39

Appendix B 41 


\section{ILLUSTRATIONS}

Figure 1. Map showing location of study area 3

2. Maps showing geology of Bear Creek and Melton Valleys 5

3. Quartile plot showing ranges of distribution of hydraulic-conductivity data for formations in Bear Creek Valley $\mathbf{1 6}$

4. Geologic section through Bear Creek Valley 19

5. Finite-difference grid for regression model $\mathbf{2 0}$

6-11. Graphs showing:

6. Percentage change in regression estimates of hydraulic conductivity compared to initial estimates 27

7. Difference between initial and model-calculated volume recharge and discharge rates $\mathbf{2 8}$

8. Initial and model-calculated coefficients of variation for hydraulic conductivity of each formation $\mathbf{3 0}$

9. Initial and model-calculated coefficients of variation for recharge and discharge zones $\mathbf{3 1}$

10. Sensitivity of simulated hydraulic heads in each formation to changes in hydraulic conductivity

11. Sensitivity of simulated hydraulic heads in each formation to changes in recharge and discharge

34

\section{Tables}

Table 1. Sources of zero hydraulic-conductivity measurements and adjusted values

2. Sources of hydraulic-conductivity data and number of tests $\mathbf{8}$

3. Ranges of hydraulic conductivity in regolith and bedrock of geologic units 9

4-8. Results of rank statistics for:

4. the deep-bedrock grouping (Set 1) 10

5. geologic unit, material type, and location (Set 2) 11

6. regolith and bedrock by geologic unit (Set 3 ) 11

7. regolith and bedrock of each geologic unit for each valley (Set 4) 12

8. Bear Creek and Melton Valleys for each geologic unit (Set 5) 13

9. Median hydraulic conductivity, 95-percent confidence limits, and coefficient of variation for geologic units $\mathbf{1 5}$

10. Initial recharge and discharge rates and coefficients of variation

23

11. Statistical results of regression model $\mathbf{2 4}$

12. Initial and regression estimates of regression parameters 


\section{FACTORS FOR CONVERTING INCH-POUND UNITS TO METRIC UNITS}

Multiply inch-pound unit

inch (in.)

foot $(\mathrm{ft})$

foot per day (ft/d)

inch per year (in/yr)

foot squared per day $\left(\mathrm{ft}^{2} / \mathrm{d}\right)$

cubic foot per day $\left(\mathrm{ft}^{3} / \mathrm{d}\right)$
By

25.4

0.3048

0.3048

2.54

0.0929

0.2832
To obtain metric unit

millimeter (mm)

meter $(\mathrm{m})$

meter per day $(\mathrm{m} / \mathrm{d})$

centimeter per year $(\mathrm{cm} / \mathrm{yr})$

meter squared per day $\left(\mathrm{m}^{2} / \mathrm{d}\right)$

cubic meter per day $\left(\mathrm{m}^{3} / \mathrm{d}\right)$

Sea level: In this report "sea level" refers to the National Geodetic Vertical Datum of 1929 (NGVD of 1929)--a geodetic datum derived from a general adjustment of the first-order level nets of both the United States and Canada, formerly called Sea Level Datum of 1929. 


\section{STATISTICAL AND SIMULATION}

ANALYSIS OF

\section{HYDRAULIC-CONDUCTIVITY DATA}

FOR BEAR CREEK AND MELTON

VALLEYS, OAK RIDGE RESERVATION,

TENNESSEE

\section{by Joseph F. Connell and Zelda Chapman Bailey}

\section{ABSTRACT}

A total of 338 single-well aquifer tests from Bear Creek and Melton Valleys were selected and statistically grouped to estimate hydraulic conductivities for the geologic formations in the valleys. Hydraulic conductivities are greater in the regolith than the bedrock in all formations except those of the Knox Group. Regolith and bedrock conductivity values could be aggregated for each formation in Bear Creek Valley except the Nolichucky Shale, and for all formations in Melton Valley except the Maryville Limestone. Bedrock deeper than 400 feet below land surface could be treated separately due to hydraulic-conductivity values that are orders of magnitude smaller than those for shallower bedrock.

$A$ cross-sectional simulation model of ground-water flow linked to a regression model was used to further refine the statistical estimates of hydraulic conductivity for each of the formations and to improve understanding of the mechanisms of ground-water flow in Bear Creek Valley. Median values of hydraulic conductivity determined for the geologic groups in Bear Creek Valley were used as initial values in the model. Model-calculated estimates of hydraulic conductivity generally were lower than the statistical estimates.

Model results indicate that initial estimates of recharge and hydraulic conductivity were probably more accurate on the Pine Ridge side of Bear Creek than on the Chestnut Ridge side. Simulations indicate that (1) the Pumpkin Valley Shale controls ground-water flow between Pine Ridge and Bear Creek, and only a small percentage of the simulated ground-water recharge from Pine Ridge reaches the Maynardville Limestone underlying Bear Creek; (2) all the recharge on Chestnut Ridge discharges to the Maynardville Limestone; (3) the formations having smaller hydraulic gradients may have a greater hydraulic conductivity parallel to strike and thus a greater tendency for flow along strike; (4) local hydraulic conditions related to fractures and cavities in the Maynardville Limestone cause inaccurate model-calculated estimates of hydraulic conductivity; and (5) the conductivity of deep bedrock neither affects the results of the model nor does it add information on the flow system.

Improved model performance and understanding of ground-water flow would require: 
(1) water-level data from additional wells in the Copper Ridge Dolomite, (2) improved estimates of hydraulic conductivity in the Copper Ridge Dolomite and Maynardville Limestone, and (3) waterlevel data and aquifer tests in additional wells in deep bedrock.

\section{INTRODUCTION}

Bear Creek and Melton Valleys are located in the Valley and Ridge physiographic province in eastern Tennessee (fig. 1), and are located within the Oak Ridge Reservation (ORR). Three facilities at the ORR [K-25, Y-12, and Oak Ridge National Laboratory (ORNL)] engage in research and development of nuclear energy and weapons, and are administered by the U.S. Department of Energy. The U.S. Geological Survey, in cooperation with the Department of Energy, is currently conducting studies of groundwater flow in Bear Creek and Melton Valleys to quantitatively define the ground-water flow system of each valley. A large amount of hydraulicconductivity data is available from both valleys, but the data vary over several orders of magnitude and have not been analyzed as one data set. Determination of representative hydraulicconductivity values for each geologic unit, for regolith, and for different depths of bedrock were needed to construct three-dimensional models of ground-water flow for the ongoing studies. This report presents the methods and analyses used to estimate hydraulic conductivity for the geologic units underlying Bear Creek Valley, adjacent ridges, and Melton Valley.

\section{PURPOSE AND SCOPE OF THE REPORT}

This report describes the results of an investigation to (1) estimate representative values of hydraulic conductivity for each geologic formation in Bear Creek and Melton Valleys, (2) evaluate the effect of the representative values on a simulation of the flow system, and
(3) identify geologic units for which additional hydrologic data are needed.

All hydraulic-conductivity data from single-well aquifer tests done prior to 1985 in Bear Creek Valley, adjacent Pine and Chestnut Ridges, and in Melton Valley were compiled. Statistical methods were used to make judgments whether differences exist between the hydraulic conductivity of regolith and bedrock for each geologic formation, and between the formations in the two valleys. The hydraulic-conductivity values determined from the statistical analyses were further refined by using a ground-water flow and regression model of a cross section through Bear Creek Valley. Estimates of recharge from a previously calibrated finitedifference model and measured water levels were also used to construct the regression model.

\section{APPROACH}

Hydraulic-conductivity data from 338 single-well aquifer tests were selected and grouped by formation and then by occurrence in bedrock and regolith for each valley. Statistical tests were done to decide if regolith and bedrock data in each formation could be combined. Statistical tests also were done to decide if data in both valleys could be combined. These data were grouped accordingly and each group was fitted to a Log-Pearson Type III continuous-frequency distribution to demonstrate the variability within each grouping. Quartile plots were constructed to compare the distribution characteristics of the groups. Median values were determined for each group of data.

The median values of hydraulic conductivity within the context of a ground-water flow system were further refined by use of a regression model (Cooley and Naff, 1985) that was constructed along a cross section through Bear Creek Valley (fig. 1). Analyses were done to determine how well the model simulated the 


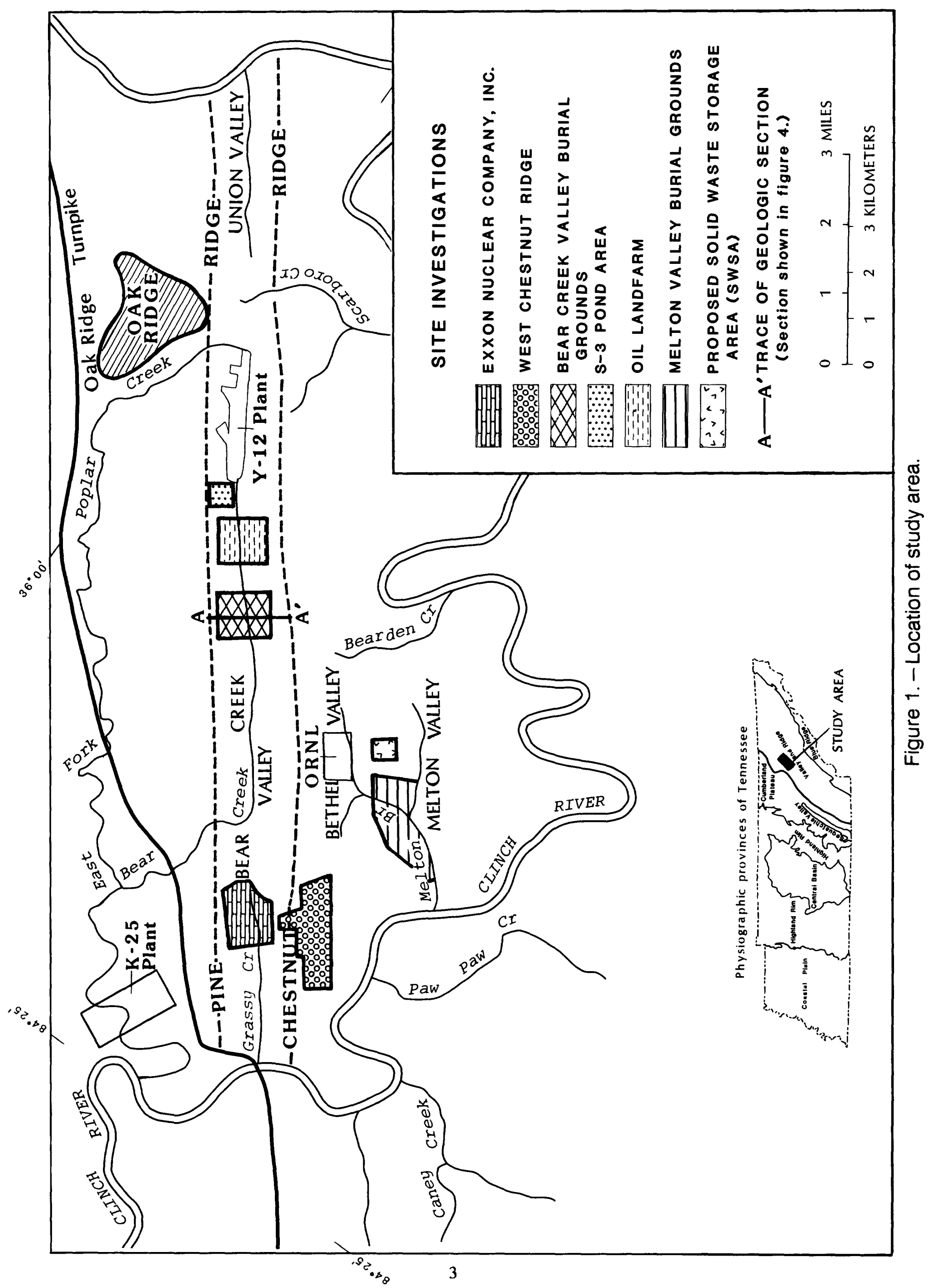


flow system and how the model responded to changes in aquifer characteristics.

\section{GEOLOGIC SETTING}

Bear Creek Valley, and adjacent Pine and Chestnut Ridges are underlain by rocks of Cambrian and Ordovician age that strike north 56 degrees east (fig. 2). The dip of the rocks varies from 30 to 70 degrees to the southeast, but the average dip is about 45 degrees. Pine Ridge is underlain by interbedded sandstone, siltstone, and shale of the Rome Formation. Bear Creek Valley is underlain by six formations comprising the Conasauga Group. From oldest to youngest these formations are: Pumpkin Valley Shale, Rutledge Limestone, Rogersville Shale, Maryville Limestone, Nolichucky Shale, and Maynardville Limestone, which contains solution cavities (Hoos and Bailey, 1986). Chestnut Ridge is underlain by massive, siliceous dolomite of the Knox Group and contains solution and karst features. Available data in the Knox Group were for the Copper Ridge Dolomite and the overlying Chepultepec Dolomite. Regolith, consisting of soil and weathered rock, overlies the bedrock and ranges from 0 to 80 feet in thickness. Regolith thickness is greatest on the ridges and may be absent beneath streams in the valleys.

Melton Valley, which is separated from Bear Creek Valley by another valley-and-ridge sequence, has the same geologic units (fig. 2) due to thrust faulting parallel to strike. The orientation of strike and dip are about the same as in Bear Creek Valley, but the dip of the rocks generally ranges from 10 to 45 degrees (Haase and others, 1985).

\section{HYDRAULIC-CONDUCTIVITY DATA}

A variety of well-construction and aquifertesting methods have been used by previous investigators at the ORR. Accuracy of the testing methods and the resulting hydraulic-conductivity values were not evaluated; the values were used as reported. A total of 418 single-well aquifer tests were considered for use, but 26 were not used because of reported problems during testing. After reviewing the results of 392 tests, hydraulic conductivity values from 338 tests were selected. The reasons for eliminating some of the available data are explained in the "Data Adjustments" section. Two hundred thirty-two tests were selected from 153 wells located in Bear Creek Valley, and 106 tests were selected from 91 wells located in Melton Valley. One hundred thirty-four tests are in regolith, 199 are in bedrock shallower than 400 feet below land surface, and 5 are in bedrock deeper than 400 feet (referred to as 'deep bedrock' in subsequent discussions).

If determination of the geologic formation being tested was not made in a referenced report, the formation was determined using well location, depth of tested interval, average dip of formation, and maps of geologic contacts (Hoos and Bailey, 1986; Tucci, 1986, p. 4). Grouping data into regolith or bedrock is difficult because the contact is usually gradational. A reported location within regolith or bedrock was assumed to be correct; however, if a distinction between regolith or bedrock was not given, a judgment was made using well logs.

\section{DATA SOURCES}

Exxon Nuclear Company, Inc. (1978) conducted a preliminary site analysis for the authorization of a proposed nuclear recovery and recycling plant (fig. 1), approximately 5 miles southwest of the Y-12 Plant. Bedrock hydraulic conductivity was determined from 138 packer tests in 22 borings, but data from 24 of the tests were reported as having measurement problems and were not used. Eight variable-head permeability tests were conducted in shallow augered borings to determine the hydraulic conductivity 


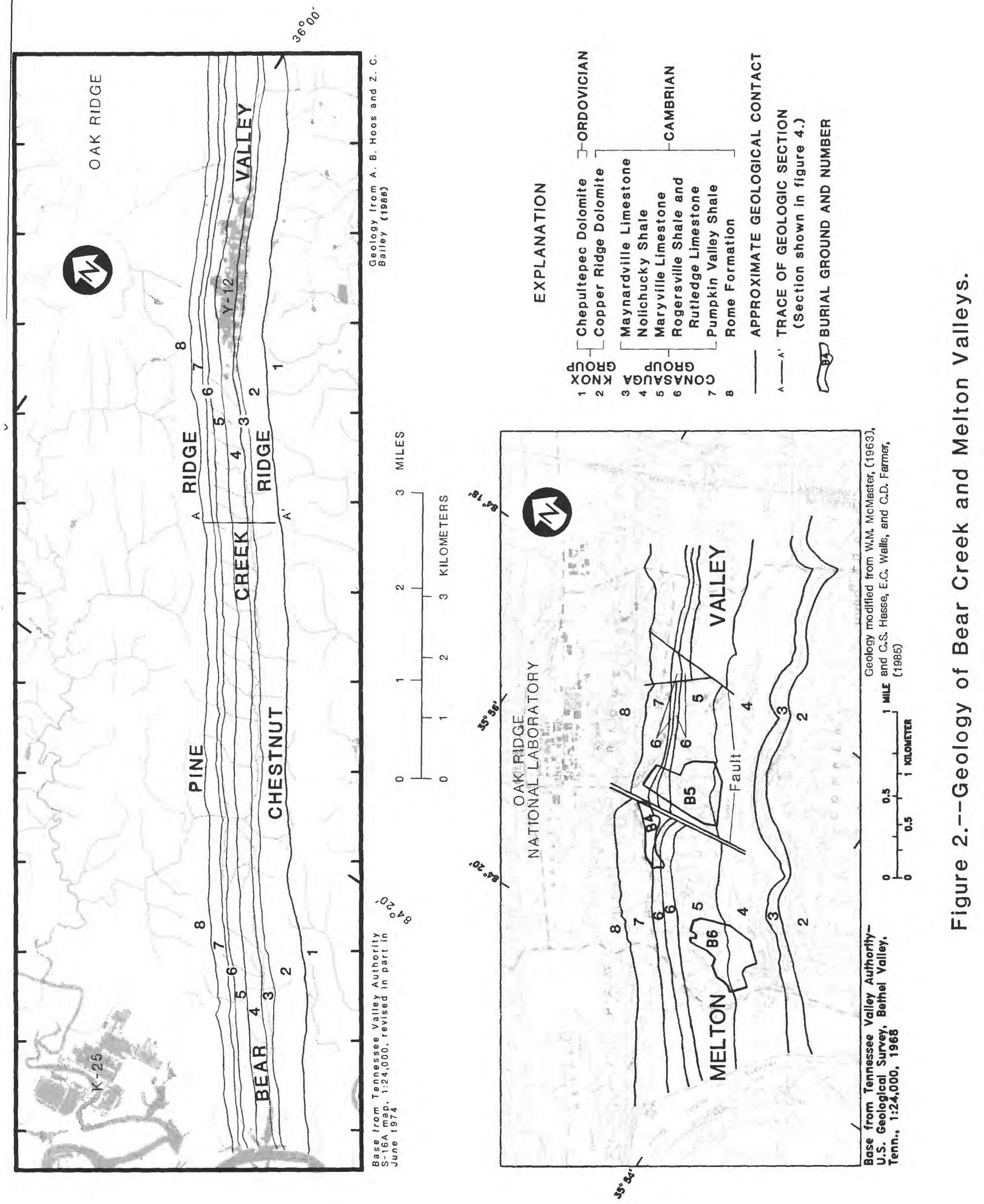


of the regolith. One test was reported to be in alluvial material near a creek and was not used because it was the only value reported from any of the studies for alluvium. Tests were performed in all formations of the Conasauga Group. The largest group, 26 tests, is from the Pumpkin Valley Shale.

Law Engineering Testing Company (written commun., 1983) performed tests on seven of the oldest Y-12 monitoring wells. Slug tests were done in five wells and packer tests in two. Fourteen bedrock and two regolith tests were conducted in the seven wells. Most of these tests were determined to be in the Pumpkin Valley or the Nolichucky Shale.

Woodward-Clyde Consultants (1984) did a subsurface investigation on West Chestnut Ridge (fig. 1) to provide data for the site characterization conducted by Ketelle and Huff (1984). Two wells were drilled at each of 20 locations and were designated as Series A borings, in regolith, and Series B borings, in relatively unweathered rock. Series A borings were drilled to equipment refusal or to a depth of 100 feet, and falling-head permeability tests were conducted to determine the hydraulic conductivity of the regolith. Only 11 of the tests in regolith are within the study area. Series B borings were generally terminated after 30 feet of relatively continuous and sound rock had been penetrated. Packer tests were conducted in the rock part of the boring; test zones were selected on the basis of geophysical and drillers logs. Only 13 of the borings were within the study area and a value of zero hydraulic conductivity was reported for 5 of those. Most of the wells were determined to be in the Copper Ridge Dolomite.

Bechtel National, Inc. (1984a) reported on the hydrogeologic conditions at Bear Creek Valley burial grounds (fig. 1). Packer permeability tests were performed in selected boreholes before observation wells were installed, and after well installation, bailer-recovery permeability tests were performed in 31 selected wells. Data were available for 33 permeability tests in bedrock and 26 in regolith. Most of the wells are located in either the Nolichucky Shale or the Maryville Limestone.

Bechtel National, Inc. (1984c) studied the western and southern perimeter of the Bear Creek Valley burial grounds (fig. 1). Six packer tests were conducted in the bedrock of three wells. Five of the tests were in the Maynardville Limestone and one was in the Copper Ridge Dolomite. The test intervals were typically associated with fractures and solution cavities.

Bechtel National, Inc. (1984b) also reported on the hydrogeologic conditions at the Oil Landfarm. Fifteen wells were drilled; 12 permeability tests were conducted in the regolith and 22 tests in the bedrock. These wells are in the Nolichucky Shale and the Maryville Limestone.

Rothschild, Turner, and others (1984b) conducted a study at the Y-12 Plant site to determine the amount of mercury in the regolith and fill material beneath the Plant. Hydraulic conductivities were determined by slug tests in 18 wells. Twelve of the tests were in slightly to moderately weathered bedrock and five were in regolith; one well was reported to be influenced by nearby pumping or by well construction problems, and consequently, was not used in this study. The majority of the wells are in the Nolichucky Shale.

Geraghty \& Miller, Inc. (1987) reported the results from falling-head tests in deep bedrock wells drilled in the Bear Creek Valley Disposal Area, which include the burial grounds, Oil Landfarm, and the S-3 Ponds (fig. 1). Fallinghead permeability tests were conducted in nine deep wells in the Maynardville Limestone, Nolichucky Shale, and Maryville Limestone. These wells ranged from 142 to 600 feet deep. Five of the wells located in the Nolichucky Shale were 
over 400 feet deep and had calculated conductivities that were orders of magnitude lower than most of the conductivities reported for the Nolichucky Shale.

Rothschild, Huff, and others (1984a) conducted a study in Melton Valley at a potential site for a solid waste storage area (SWSA). Twenty slug tests were conducted in 12 wells; 12 tests were in bedrock and 8 in regolith. The wells were determined to be in the Nolichucky Shale or the Maryville Limestone, except for one in the Rogersville Shale.

David Webster (U.S. Geological Survey, written commun., 1984) reported the results from slug tests on wells in Melton Valley burial grounds (fig. 1). Twenty-three slug tests were made in bedrock and 63 were made in the regolith. The majority of the wells were determined to be in the Maryville Limestone or the Pumpkin Valley Shale.

\section{DATA ADJUSTMENTS}

Exxon Nuclear Company, Inc. (1978) and Law Engineering Testing Co. (written commun., 1983) reported 12 wells with five or more aquifer tests in the same well but at different depth intervals in the same geologic formation. For this study, the number of values from one well for one geologic unit was limited to a maximum of four so that data from one well location would not overly influence the areal average. The middle four values were used if the number of multiple measurements in a unit was even, and the middle three were used if the number was odd. This procedure prevented extreme values from biasing the data. Fifty-two values were excluded from 11 well sites tested by Exxon Nuclear Company, Inc., and 2 values from 1 well tested by Law Engineering Testing Company.

Of the 338 remaining hydraulicconductivity values used for this study, 22 were zero (table 1). These zero values were assumed to represent conductivities too low to be detected by the measuring techniques. In order to facilitate analysis, a value of one-third of the minimum non-zero observation was arbitrarily assigned to each reported zero observation in each data set from a particular measurement. These 22 values were adjusted from the zero value accordingly, and ranged from $1.7 \times 10^{-3}$ to $1.8 \times 10^{-5} \mathrm{ft} / \mathrm{d}$.

The final data set consists of 338 hydraulicconductivity values; 134 in regolith, 199 in bedrock, and 5 in deep bedrock. A summary of the data is presented by source in table 2 , and by formation in each valley in table 3.

Table 1.--Sources of zero hydraulic-conductivity measurements and adjusted values

\begin{tabular}{|c|c|c|c|}
\hline Source of data & $\begin{array}{l}\text { Number } \\
\text { of zero } \\
\text { values }\end{array}$ & $\begin{array}{l}\text { Minimum reported } \\
\text { hydraulic conductivity, } \\
\text { in feet per day }\end{array}$ & $\begin{array}{c}\text { Adjusted } \\
\text { hydraulic } \\
\text { conductivity, } \\
\text { in feet per day }\end{array}$ \\
\hline $\begin{array}{l}\text { Exxon Nuclear Company, Inc., } 1978 \\
\text { Woodward-Clyde Consultants, } 1984 \\
\text { Geraghty \& Miller, Inc., } 1987\end{array}$ & $\begin{array}{r}43 \\
5 \\
1\end{array}$ & $\begin{array}{l}0.0014 \\
.005 \\
.000055\end{array}$ & $\begin{array}{l}0.00046 \\
.0017 \\
.000018\end{array}$ \\
\hline Total & $\overline{49}$ & & \\
\hline
\end{tabular}


Table 2.--Sources of hydraulic-conductivity data and number of tests

\begin{tabular}{cccc}
\hline Source of data & \multicolumn{3}{c}{ Number of tests } \\
\cline { 2 - 4 } & Regolith & Bedrock & Deep bedrock \\
\hline Bear Creek Valley & & & \\
Exxon Nuclear Company, Inc. (1978) & 7 & 62 & \\
Law Engineering Testing Co. & 2 & 12 & \\
$\quad$ (written commun., 1983) & 11 & 13 & \\
Woodward-Clyde Consultants (1984) & 26 & 33 & \\
Bechtel National, Inc. (1984a) & 0 & 6 & 5 \\
Bechtel National, Inc. (1984b) & 12 & 22 & \\
Bechtel National, Inc. (1984c) & 5 & 12 & \\
Rothschild and others (1984b) & & 4 & \\
Geraghty \& Miller, Inc. (1984) & 63 & 164 & \\
Subtotal & & & \\
Melton Valley & 8 & 12 & \\
Rothschild and others (1984a) & $\underline{63}$ & $\underline{23}$ \\
Webster (written commun., 1984) & $\underline{71}$ & $\underline{35}$ \\
Subtotal & $\underline{134}$ & 199 & 5 \\
$\quad$ Total &
\end{tabular}

\section{STATISTICAL ANALYSIS}

Aggregation of hydraulic-conductivity data was determined by five sets of statistical analyses that were done to evaluate differences of hydraulic conductivity:

Set 1. Between deep bedrock and shallower bedrock;

Set 2. Between geologic formations, material type (regolith or bedrock), and location;

Set 3. In material type by combining all data by geologic formation;

Set 4. In material type (regolith or bedrock) by combining all data by geologic unit within each valley; and

Set 5. Between the two valleys for each geologic formation.

\section{METHODS}

Hydraulic conductivities were highly variable and ranged over three orders of magnitude in some subgroups (table 3 ). This large range of values may be due in part to the variability in local hydraulic characteristics caused by fractures and solution cavities. Data of this nature, which are bound by zero and are unconstrained in the upper range, do not follow a normal distribution (Viessman and others, 1977, p. 74). Power or logarithmic transformations can be used to normalize the data, or rank statistics, which do not require the assumption of normality, may be used. Because nonnormal populations are difficult to detect in small sample sizes (Iman and Conover, 1983, p. 280) and approximately one-half of the samples in this study contained less than 10 observations (table 3 ), rank statistics were used. 
Table 3.--Ranges of hydraulic conductivity in regolith and bedrock of geologic units

\begin{tabular}{|c|c|c|c|c|c|c|}
\hline \multirow{2}{*}{$\begin{array}{l}\text { Geologic unit } \\
\text { and location } \\
\text { (statistical } \\
\text { subgroups) }\end{array}$} & \multicolumn{3}{|c|}{ Regolith } & \multicolumn{3}{|c|}{ Bedrock } \\
\hline & $\begin{array}{l}\text { Number of } \\
\text { observations }\end{array}$ & $\begin{array}{l}\text { Ran } \\
\text { hydr } \\
\text { condu } \\
\text { in feet }\end{array}$ & $\begin{array}{l}\text { ge of } \\
\text { raulic } \\
\text { uctivity, } \\
\text { per day }\end{array}$ & $\begin{array}{l}\text { Number of } \\
\text { observations }\end{array}$ & $\begin{array}{r}\text { Rang } \\
\text { hydra } \\
\text { s conduc } \\
\text { in feet } p\end{array}$ & $\begin{array}{l}\text { ge of } \\
\text { raulic } \\
\text { uctivity, } \\
\text { per day }\end{array}$ \\
\hline Bear Creek Valley & -- & & -- & 5 & 0.00002 & -0.00014 \\
\hline $\begin{array}{c}\text { Chepultepec Dolomite } \\
\text { Bear Creek Valley }\end{array}$ & 5 & 0.00016 & -0.045 & 9 & .00018 & - 3.97 \\
\hline $\begin{array}{l}\text { Copper Ridge Dolomite } \\
\text { Bear Creek Valley }\end{array}$ & 5 & .00074 & -1.39 & 5 & .0018 & -11.6 \\
\hline $\begin{array}{l}\text { Maynardville Limestone } \\
\text { Bear Creek Valley }\end{array}$ & 5 & .063 & -136 & 13 & .031 & -70.3 \\
\hline $\begin{array}{l}\text { Nolichucky Shale } \\
\text { Bear Creek Valley } \\
\text { Melton Valley }\end{array}$ & $\begin{array}{l}24 \\
12\end{array}$ & $\begin{array}{l}.037 \\
.24\end{array}$ & $\begin{array}{ll}- & 3.25 \\
- & 6.7\end{array}$ & $\begin{array}{r}45 \\
4\end{array}$ & $\begin{array}{l}.00046- \\
.107\end{array}$ & $\begin{array}{lc}- & 7.94 \\
- & .867\end{array}$ \\
\hline $\begin{array}{l}\text { Maryville Limestone } \\
\text { Bear Creek Valley } \\
\text { Melton Valley }\end{array}$ & $\begin{array}{l}15 \\
35\end{array}$ & $\begin{array}{l}.03 \\
.00065\end{array}$ & $\begin{array}{l}-\quad 2.08 \\
-\quad 5.37\end{array}$ & $\begin{array}{l}33 \\
28\end{array}$ & $\begin{array}{l}.00045- \\
.00015-\end{array}$ & $\begin{array}{ll}- & 2.08 \\
- & .227\end{array}$ \\
\hline $\begin{array}{l}\text { Rogersville Shale and } \\
\text { Rutledge Limestone. } \\
\text { Bear Creek Valley } \\
\text { Melton Valley }\end{array}$ & $\begin{array}{l}5 \\
8\end{array}$ & $\begin{array}{l}.052 \\
.017\end{array}$ & $\begin{array}{ll}- & .28 \\
- & .758\end{array}$ & $\begin{array}{r}20 \\
3\end{array}$ & $\begin{array}{l}.00046- \\
.00035-\end{array}$ & $\begin{array}{l}.55 \\
.023\end{array}$ \\
\hline $\begin{array}{l}\text { Pumpkin Valley Shale } \\
\text { Bear Creek Valley } \\
\text { Melton Valley }\end{array}$ & $\begin{array}{r}4 \\
16\end{array}$ & $\begin{array}{l}.044 \\
.010\end{array}$ & $\begin{array}{ll}- & 1.17 \\
- & .938\end{array}$ & 26 & $.00046-$ & .84 \\
\hline $\begin{array}{l}\text { Rome Formation } \\
\text { Bear Creek Valley }\end{array}$ & -- & & -- & 13 & .0082 & - 7.37 \\
\hline Total & $\overline{134}$ & & & $\overline{204}$ & & \\
\hline
\end{tabular}

A two-sample t-test on ranks, which is equivalent to the Wilcoxon-Mann-Whitney rank-sum test, was used to decide if differences exist between sample means. The null hypothesis is $H_{0}: \bar{R} x^{\prime}=\bar{R} y^{\prime}$ versus the alternate hypothesis of $\mathrm{H}_{1}: \overline{\mathrm{R}} \mathrm{x}^{\prime} \neq \overline{\mathrm{R} y^{\prime}}$, and alpha $=0.05$.
The test statistic (T) for the t-test on ranks is calculated as follows:

$T=\frac{\left(\bar{R} x^{\prime}-\bar{R} y^{\prime}\right)}{\sqrt{S^{2}\left(\frac{1}{N x}+\frac{1}{N y}\right)}}$ 
where

$\mathrm{T}$ is the test statistic from the rank calculations,

$\bar{R} x^{\prime}$ is the first sample mean of the ranks, which is the median of the regolith or the median of Bear Creek Valley hydraulic-conductivity value;

$\bar{R} y^{\prime}$ is the second sample mean of the ranks, which is the median of the bedrock or the median of Melton Valley hydraulicconductivity value;

$\mathrm{Nx}$ is the size of the first sample;

$\mathrm{Ny}$ is the size of the second sample; and

$\mathrm{Sp}^{2}$ is the pooled variance of the ranks.

Only two-tailed t-tests were done because it was not known which sample had the higher hydraulic conductivity. Tests were not done for groups having fewer than three observations. The decision rule to reject $\mathrm{H}_{\mathrm{o}}$ was $\mathrm{T}>\mathrm{t}_{0.025}$ or $\mathrm{T}<\mathrm{t}_{0.025 \text {. }}$

If more than two groups were involved, such as for the seven geologic formations, the one-way analysis of variance on the ranktransformed data is an appropriate test and is equivalent to the Kruskal-Wallis test (Iman and Conover, 1983), which was used to decide if a difference exists among the groups. The null hypothesis is $H_{0}: \bar{R} 1=\bar{R} 2 \ldots=\bar{R} i$ (all the rank means are equal) at alpha $=0.05$. The alternate hypothesis is $\mathrm{H}_{1}$ : $\overline{\mathrm{R}} \mathrm{k} \neq \overline{\mathrm{R}} \mathrm{j}$ (at least two population means are unequal). The F-statistic for the test is calculated as follows:

$$
\mathrm{F}=\frac{\mathrm{MST}}{\mathrm{MSE}}
$$

where

$F$ is the test statistic derived from the rank calculations,

MST is the mean square of the treatment

(hydraulic conductivity of the geologic formation), and

MSE is the mean square of the error.

The decision rule is to reject $\mathrm{H}_{\mathrm{o}}$ : if $\mathrm{F}>\mathrm{f}_{0.05}$.

\section{RESULTS OF STATISTICAL TESTS}

Rank t-tests were done for set 1 to evaluate differences between deep bedrock and shallower bedrock. All of the deep-bedrock wells, located in the Nolichucky Shale in Bear-Creek Valley, were compared with the bedrock wells located in the Nolichucky Shale for both valleys (table 4). In both cases the $\mathrm{p}$-value (exceedance probability associated with the T-statistic) is less than 0.01 and deep bedrock was considered to be a valid separate grouping.

Regolith and bedrock (excluding deepbedrock data) for the remaining sets of analyses were subdivided by formation for both Bear Creek and Melton Valleys. Data from the formations in the Knox Group and the Rome Formation, although located on Chestnut and Pine Ridges, respectively, were subdivided as part of the Bear Creek Valley data. Because the

Table 4.--Results of rank statistics for the deep-bedrock grouping (Set 1)

\begin{tabular}{lcccc}
\hline Location of wells & $\begin{array}{c}\text { Degrees of } \\
\text { freedom }\end{array}$ & $T$ & $p$-value & $t(0.05)$ \\
\hline Nolichucky Shale & & & & \\
Bear Creek Valley & 48 & 4.22 & $<0.01$ & 2.01 \\
Melton Valley & 7 & 4.66 & $<.01$ & 2.36 \\
\hline
\end{tabular}


Rutledge Limestone and Rogersville Shale are thin in comparison to other units in the Conasauga Group and difficult to distinguish due to their similar interbedded nature, their data were aggregated. The Rutledge Limestone and Rogersville Shale have similar lithologies and their hydraulic characteristics may also be similar. The remaining formations in the Conasauga Group were grouped separately (table 3 ).

Data were grouped by geologic unit, material type, and location for set 2. Rank, oneway analysis of variance (equation 2) was used to test if differences exist between geologic units, and rank t-tests (equation 1) were used to test for differences in material type (regolith versus bedrock) and location (Bear Creek versus Melton Valley). The results are summarized in table 5.
There are substantial differences between the geologic units, and hydraulic conductivities from wells in the regolith are greater than from wells in the bedrock. Although the overall conductivities are larger in Bear Creek Valley than in Melton Valley, as indicated by the positive $t$, the difference is not statistically significant (table 5).

The ranked t-test (equation 1) was used to determine if there were overall differences between hydraulic-conductivity values from regolith and from bedrock for each geologic unit (set 3 ). The results are presented in table 6 for all units except the Rome Formation for which there were insufficient data. Hydraulic conductivities from regolith wells are greater than those from bedrock wells, as indicated by positive T-values, for all formations except those in the

Table 5.--Results of rank statistics for geologic unit, material type, and location (Set 2)

\begin{tabular}{|c|c|c|c|c|}
\hline $\begin{array}{l}\text { Rock type } \\
\text { or location }\end{array}$ & $\begin{array}{l}\text { Degrees of } \\
\text { freedom }\end{array}$ & $\mathrm{F}$ or $\mathrm{T}$ & $p$-value & $\begin{array}{l}\text { F or } t \\
(0.05)\end{array}$ \\
\hline $\begin{array}{l}\text { Geologic unit } \\
\text { Regolith - bedrock }\end{array}$ & $\begin{array}{r}6,326 \\
331\end{array}$ & $\begin{aligned} & F= 9.25 \\
& 4.7\end{aligned}$ & $\begin{array}{l}<0.01 \\
<\quad .01\end{array}$ & $\begin{array}{l}2.1 \\
1.96\end{array}$ \\
\hline $\begin{array}{l}\text { Melton Valley - } \\
\text { Bear Creek Valley. }\end{array}$ & 331 & .16 & .87 & 1.96 \\
\hline
\end{tabular}

Table 6.--Results of rank statistics for regolith and bedrock by geologic unit (Set 3)

\begin{tabular}{lcccc}
\hline Geologic unit & $\begin{array}{c}\text { Degrees of } \\
\text { freedom }\end{array}$ & $T$ & $p$-value & $t(0.05)$ \\
\hline Chepultepec Dolomite & 12 & -1.64 & 0.13 & 2.18 \\
Copper Ridge Dolomite & 8 & -.5 & .63 & 2.31 \\
Maynardville Limestone & 16 & .93 & .36 & 2.12 \\
Nolichucky Shale & 83 & 3.45 & $<.01$ & 1.99 \\
Maryville Limestone & 109 & 5.63 & $<.01$ & 1.96 \\
Rogersville Shale and & & 3.18 & $<.01$ & 2.03 \\
$\quad$ Rutledge Limestone. & 34 & 2.02 & .049 & 2.02 \\
Pumpkin Valley Shale & 44 & & & \\
\hline
\end{tabular}


Knox Group (the Chepultepec and Copper Ridge Dolomites). However, of the remaining formations only the Rutledge Limestone and Rogersville Shale, the Nolichucky Shale, and the Maryville Limestone have significantly larger hydraulic conductivity for wells in regolith than in bedrock.

Set 4 analyses, similar in procedure to those for set 3, were done for each location, Bear Creek and Melton Valleys, for differences between hydraulic-conductivity data from regolith and from bedrock in each geologic unit (table 7). Positive T-values indicate larger hydraulic conductivities in regolith for all units tested. In Bear Creek Valley, the only unit with a p-value less than 0.05 was the Nolichucky Shale, but in Melton Valley, all units had a p-value less than 0.05 except the Nolichucky Shale.

Results of the rank t-test for set 5 , differences in hydraulic conductivity between Bear Creek and Melton Valleys for each geologic unit, are given in table 8 . Only seven rank $\mathrm{t}$-tests were conducted because of insufficient data for Mel- ton Valley. With the exception of the regolith overlying the Pumpkin Valley Shale, hydraulic conductivities from wells in the regolith are greater in Melton Valley than in Bear Creek Valley for all formations tested. Except for the Nolichucky Shale, the hydraulic-conductivity values for bedrock are greater in Melton Valley than in Bear Creek Valley, particularly in the Maryville Limestone.

\section{GROUPING OF HYDRAULIC- CONDUCTIVITY DATA}

The purpose of the five sets of analyses was to evaluate whether the initial subgroupings (table 3) of data by formation and valley were statistically valid and whether some of the subgroups could be combined. As a result of the analyses, the original 23 subgroupings (table 3 ) were reduced to 14 groups (table 9). The following discussions elaborate on use of the statistical criteria and the decision-making process for each of the 14 groups.

Table 7.--Results of rank statistics for regolith and bedrock of each geologic unit for each valley (Set 4)

\begin{tabular}{|c|c|c|c|c|}
\hline Geologic unit & $\begin{array}{c}\text { Degrees of } \\
\text { freedom }\end{array}$ & $\mathrm{T}$ & $p$-value & $t(0.05)$ \\
\hline \multicolumn{5}{|l|}{ Bear Creek Valley } \\
\hline Maynardville Limestone & 16 & 0.93 & 0.36 & 2.12 \\
\hline Nolichucky Shale & 67 & 2.48 & .016 & 2.00 \\
\hline Maryville Limestone & 46 & 1.38 & .17 & 2.01 \\
\hline \multicolumn{5}{|l|}{ Rogersville Shale and } \\
\hline Rutledge Limestone. & 23 & 1.74 & .096 & 2.07 \\
\hline Pumpkin Valley Shale & 28 & 1.37 & .18 & 2.05 \\
\hline \multicolumn{5}{|l|}{ Melton Valley } \\
\hline Nolichucky Shale & 14 & 1.37 & .19 & 2.14 \\
\hline Maryville Limestone & 61 & 7.24 & $<.01$ & 2.00 \\
\hline $\begin{array}{l}\text { Rogersville Shale and } \\
\text { Rutledge Limestone. }\end{array}$ & 9 & 3.03 & .014 & 2.26 \\
\hline
\end{tabular}


Table 8.--Results of rank statistics for Bear Creek and Melton Valleys

for each geologic unit (Set 5)

Geologic unit
Degrees of freedom

Nolichucky Shale

Regolith

Bedrock

34

47

$-1.5$

0.14

2.04

.47

2.01

Maryville Limestone

Regolith

48

$-1.69$

.097

2.01

Bedrock

59

3.05

$<.01$

2.00

Rogersville Shale and

Rutledge Limestone

Regolith

11

21

$-.87$

1.83

.4

2.26

Bedrock

Pumpkin Valley Shale

Regolith

18

2.04

.056

2.09

All of the deep-bedrock wells are located in Bear Creek Valley in the Nolichucky Shale. Tests for differences in hydraulic conductivity between deep bedrock and shallower bedrock strongly indicated that deep bedrock is an appropriate grouping. Although deep-bedrock data were not avaliable for the formations other than the Nolichucky Shale, these values of hydraulic conductivity are probably more representative of the deep bedrock in other units than values from the relatively shallow bedrock.

The differences between regolith and bedrock in the Chepultepec and Copper Ridge Dolomites are not significant (table 6), which indicates that the regolith and bedrock data from each of these formations can be aggregated. All hydraulic-conductivity values for these two formations in the Knox Group are from Chestnut Ridge, which is adjacent to Bear Creek Valley.

All the wells in the Maynardville Limestone are located in Bear Creek Valley, and, as a result of cavities reported near the test interval in 7 of the 19 aquifer tests in the Maynardville Limestone, the hydraulic-conductivity values ranged over three orders of magnitude, from 0.031 to 136.0 feet per day (table 3 ). This variability causes difficulty in detecting differences between hydraulic conductivity of regolith and bedrock (material type), even if the differences exist. Because p-values (table 6) did not indicate a difference in the material type, the regolith and bedrock data in the Maynardville Limestone were combined in one group.

A substantial overall difference exists between regolith and bedrock hydraulicconductivity values in the Nolichucky Shale (table 6). This difference was more pronounced in Bear Creek Valley than in Melton Valley (table 7), and is at least partially due to the larger number of observations in Bear Creek Valley compared to Melton Valley. No difference in regolith or bedrock between valleys was indicated (table 8), and therefore, the data were partitioned by material type but not by valley. 
A substantial overall difference exists between hydraulic conductivity of regolith and bedrock in the Maryville Limestone (table 6). However, when the data were partitioned by valleys, this difference was apparent in Melton Valley but not in Bear Creek Valley (table 7). There was a significant difference between bedrock data for the valleys, but a difference in values for regolith between the two valleys was questionable because of a low p-value (table 8). However, because there was a difference in hydraulic conductivity between valleys for bedrock, and a large number of both bedrock and regolith data were available for the Maryville Limestone in Melton Valley, the regolith data were also separated by valley. In summary, regolith and bedrock data for Maryville Limestone were combined for Bear Creek Valley, but not for Melton Valley.

A substantial overall difference exists between all the regolith and bedrock hydraulicconductivity values from the Rutledge Limestone and Rogersville Shale (table 6). However, differences did not exist between data for regolith and bedrock in Bear Creek Valley, so the data were combined. Only three observations were available for bedrock, in Melton Valley, and although the analyses indicate a significant difference, the small sample size may give misleading results. Therefore, regolith and bedrock data were combined in Melton Valley.

The analyses for a difference between the combined regolith and bedrock hydraulicconductivity data from the Pumpkin Valley Shale indicates that there is a difference. All bedrock data for the Pumpkin Valley Shale are from Bear Creek Valley, but 16 of the 20 values for regolith are from Melton Valley. The difference between regolith and bedrock was not evident when the analyses were done for Bear Creek Valley, and a similar analysis could not be conducted for Melton Valley due to the lack of bedrock data. Although there was not a significant difference in the regolith between valleys, the p-value (table 8 ) was very close to the value for rejecting the null hypothesis. Therefore, regolith and bedrock data were combined for the Pumpkin Valley Shale in Bear Creek Valley. Regolith data were a separate grouping in Melton Valley, and there is no bedrock group for Melton Valley.

Because all the hydraulic-conductivity measurements for the Rome Formation were in bedrock in Bear Creek Valley, no analysis could be done for regolith combinations or for Melton Valley.

In summary, the final 14 groupings consist of combined regolith and bedrock data, when data existed in both groups, in all the formations in Bear Creek Valley except for the Nolichucky Shale and all formations in Melton Valley, except for the Maryville Limestone (table 9).

\section{FREQUENCY ANALYSES AND QUARTILE PLOTS}

Frequency analysis was used to show the range and relation of the data within each group that was established by the rank statistics. A technique was developed to calculate the standard deviates of the ranked data (appendix A). A program was developed that extracts the data from data-management files, calculates using the technique in Appendix A, and plots the results on frequency graphs.

Hydraulic-conductivity data have been reported to follow a log-normal distribution, but exceptions exist (Freeze, 1975, p. 728). The data sets for Bear Creek and Melton Valleys appeared to be exceptions, and consequently, a LogPearson Type III distribution, which is a generalization of $\log$ normal and has a skew coefficient, was selected for plotting all the groups (Appendix B). About half of the plots of the data from Bear Creek and Melton Valleys are log normal (straight line), and about half are LogPearson (skewed). 
Median values were close to those determined in the statistical analyses (table 9). The 95-percent confidence limits (table 9) for the median values were determined from the frequency plots of each of the groups.
Distribution characteristics of the Bear Creek Valley data sets can be compared on quartile plots (fig. 3). These plots display the medians, interquartile range, outerquartile range, and any extreme values (Tufte, 1983). The

Table 9.--Median hydraulic conductivity, 95-percent confidence limits, and coefficient of variation for geologic units

\begin{tabular}{|c|c|c|c|c|}
\hline \multirow[b]{2}{*}{$\begin{array}{c}\text { Geologic } \\
\text { unit and location }\end{array}$} & \multirow[b]{2}{*}{$\begin{array}{l}\text { Number of } \\
\text { observations }\end{array}$} & \multicolumn{3}{|c|}{ Hydraulic conductivity } \\
\hline & & $\begin{array}{l}\text { Median, } \\
\text { in feet } \\
\text { per day }\end{array}$ & $\begin{array}{l}\text { 95-percent con- } \\
\text { fidence limit, in } \\
\text { feet per day }\end{array}$ & $\begin{array}{l}\text { Coefficient } \\
\text { of } \\
\text { variation }\end{array}$ \\
\hline
\end{tabular}

Deep bedrock Bear Creek
5
0.000078
$0.000036-0.00017$
0.26

Chepultepec Dolomite

Bear Creek Valley *1

14

.0134

$.0035 \quad-.0512$

1.66

Copper Ridge Dolomite

Bear Creek Valley *1

10

.0419

$.0061 \quad-.2870$

3

Maynardville Limestone

Bear Creek Valley *1

18

1.16

$.437-3.069$

1.08

Nolichucky Shale

Regolith *2

Bedrock *2

Maryville Limestone

Bear Creek *1

Melton Valley-regolith

Melton Valley-bedrock

Rogersville Shale and

Rutledge Limestone.

Bear Creek Valley *1

Melton Valley *1

Pumpkin Valley Shale

Bear Creek Valley *1

Melton Valley-regolith

36

49

.592

.138

$.4130-.8470$

.36

$.0752-.2520$

.64

48

35

28

\section{.11}

.361

.0182

$.0683-.1780$

.5

$.2200-.5930$

.51

$.0104-.0318$
25

11

.035

.066

30

16

.0194

.0362

Rome Formation

Bear Creek Valley-bedrock

$.0170-.0710$

$.018-.2470$

.75

1.96

13

.439

$.0084-.0448$

.92

$.0191-.0687 \quad .65$

*1 Includes both regolith and bedrock data.

*2 Includes data from Bear Creek and Melton Valleys. 


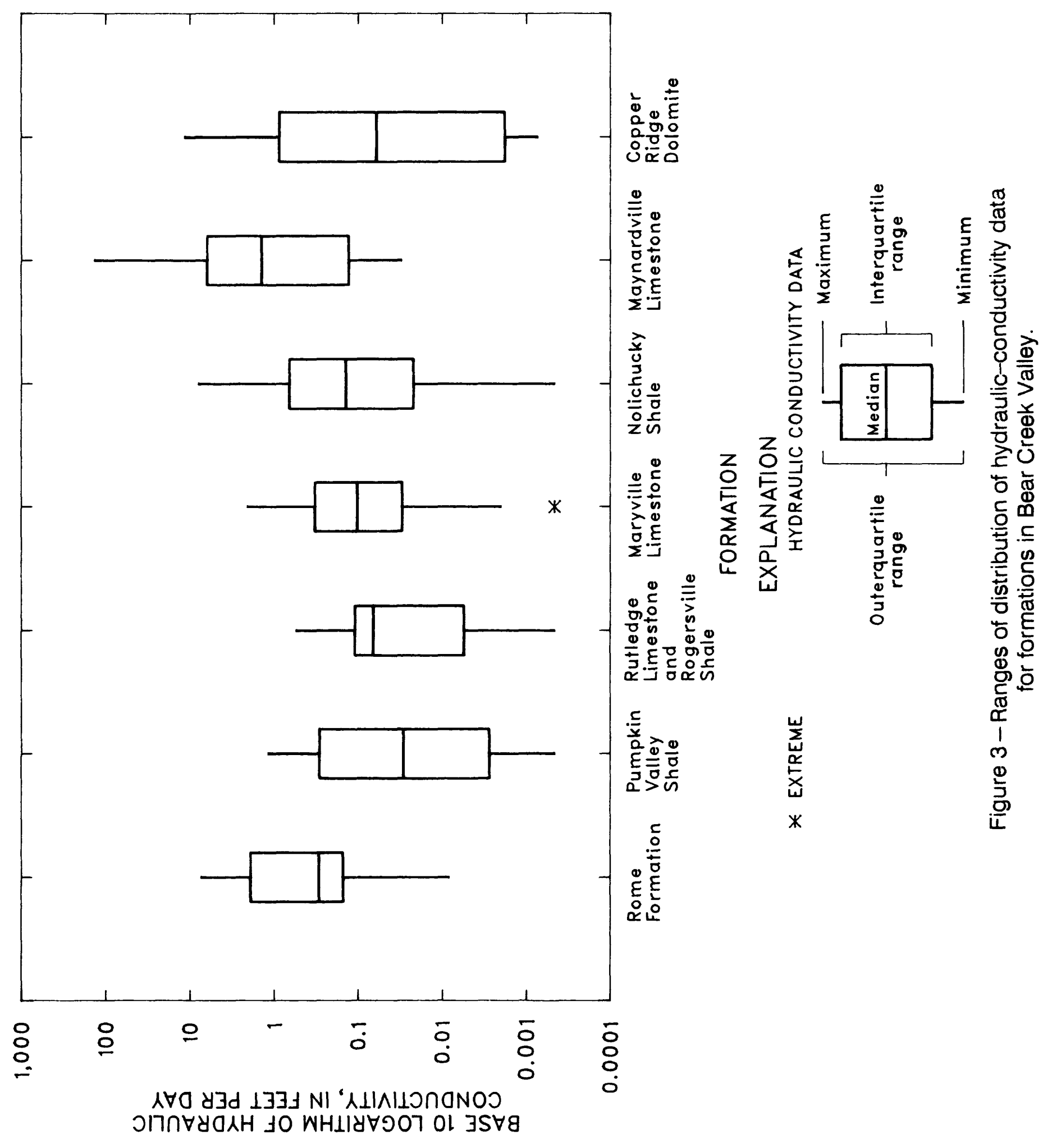


interquartile range comprises the middle 50 percent of the data; 25 percent above the median and 25 percent below the median. The outerquartile range comprises the remaining 50 percent of the data if maximum and minimum values fall within plus or minus 1.5 interquartile ranges of the respective quartiles. In all the data sets except the Maryville Limestone, the outerquartile range includes all the data. Extreme values, values that fall outside the outerquartile range, only occurred in data for the Maryville. The log (base-ten) of the data was used because the data varied over four orders of magnitude. Except for a sharp decrease in the median between the Rome Formation and the Pumpkin Valley Shale, the median hydraulic conductivity gradually increases from Pine Ridge toward Bear Creek. The smaller data sets, the Rome Formation, Maynardville Limestone, and the Copper Ridge Dolomite, are skewed more than the larger data sets as shown by the unequal interquartile and outerquartile ranges (fig. 3). Insufficient data from Melton Valley prevented construction of a meaningful quartile plot.

\section{SIMULATION ANALYSIS OF HYDRAULIC CONDUCTIVITY AND GROUND-WATER FLOW}

A ground-water flow and regression model (Cooley and Naff, 1985) was used to further refine the hydraulic-conductivity values determined in the statistical analyses and to better understand the mechanisms of ground-water flow. The model is composed of two parts: (1) a ground-water flow model that uses an integrated finite-difference technique to solve the flow equations, and (2) a regression procedure that solves for optimum model hydraulic characteristics (regression parameters) by minimizing the sum of the squared errors of head differences between model-simulated heads and observed heads. Regression parameters can be hydraulic conductivity, constant head, head-dependent flux, source or sink terms, areal recharge, or boundary flux. Prior information about the regression parameters, in the form of initial estimates of coefficient of variation, may be incorporated into the model to improve the results. Basic assumptions of the regression model are that residuals are normally distributed random variables and that the regression parameters are uncorrelated. The regression procedure includes calculation of the sensitivity of hydraulic head to each regression parameter, and allows determination of the sensitivity of any part of the model to a change in a regression parameter. A standard deviation, which indicates how well the regression parameters are determined by the model, is calculated by the model for each regression parameter.

\section{APPLICATION OF GROUND-WATER FLOW AND REGRESSION MODEL TO BEAR CREEK VALLEY}

A section across Bear Creek Valley was selected for model simulation because a finitedifference cross-sectional model had already been done (Bailey, 1988). This was the only location in either valley that provided sufficient data to construct and calibrate a cross-sectional model. The concepts developed for and results from the finite-difference model were used as prior information and initial values for the regression model. Although the regression model is discretized differently, it is constructed on the same cross section, uses the same watertable elevation and observation-well data, and uses a similar pattern of recharge rates and distribution as the finite-difference model.

\section{Description of Model Area}

The modeled cross section transects the Rome Formation, Pumpkin Valley Shale, Rutledge Limestone and Rogersville Shale, Maryville Limestone, Nolichucky Shale, Maynardville Limestone, and Copper Ridge Dolomite (fig. 2), 
all of which dip at approximately 45 degrees (fig. 4). The northwestern boundary is the surfacewater divide on Pine Ridge, which is underlain by the Rome Formation and the southeastern boundary is the surface-water divide on Chestnut Ridge, underlain by the Copper Ridge Dolomite. The modeled area is 4,050 feet in length, and the elevation is from 300 to 1,050 feet above sea level. Averages of water levels measured during October 1986 from 28 wells were used as observations in the regression model. Nine of these wells are screened in the water table. The model grid (fig. 5) was divided into nine areas of hydraulic conductivity, which corresponds to the geologic formations and the statistical groups (table 9) for Bear Creek Valley excluding the Chepultepec Dolomite.

\section{Assumptions}

The following simplifications and assumptions were made to simulate the complex hydrologic system in the cross section:

1. Ground-water flow is laminar. Although, this assumption may be violated locally in large limestone cavities, such as those in the Maynardville Limestone, the model represents flow on a regional scale.

2. The system is at steady state. Changes in storage are negligible.

3. Within each formation the aquifer is homogeneous and isotropic.

4. The section is along a single flow line.

5. The lateral limits of the model (surfacewater divides) are also ground-water divides.

6. Bedrock below an elevation of 300 feet above sea level is impermeable and forms the lower boundary of the model.

7. The water table is the upper boundary of the model and is the only area to receive recharge.

\section{Model Construction}

A model grid, having mesh-centered nodes, was constructed to locate nodes at the screened interval of each well and to delinate areas of different hydraulic conductivity. Additional nodes were placed in the Copper Ridge Dolomite where the steepest gradients occurred. A total of 31 columns along the traverse and 19 rows in the vertical direction (fig. 5), were used to model the area. The upper surface of the grid conforms to the water table.

\section{Hydraulic Conductivity}

Initial hydraulic-conductivity values for the model were the median values determined by statistical analyses (table 9). Regolith and bedrock were combined for all formations in Bear Creek Valley except for the Nolichucky Shale, which has a statistical difference between the hydraulic conductivity of regolith and bedrock. Deep bedrock, below an elevation of 500 feet above sea level, was assigned a single hydraulic-conductivity value throughout the model.

\section{Water-Table Conditions}

Heads in three nodes were specified as water-table boundary conditions for the model: (1) 1,045 feet above sea level for the groundwater divide on Pine Ridge, (2) 1,005 feet for the ground-water divide on Chestnut Ridge, and (3) 886.4 feet near Bear Creek. The specified heads on the ridges were estimated from a water-table map (Bailey, 1988) that included data from nearby wells on Pine Ridge, and the specified head near Bear Creek was measured in an observation well. 


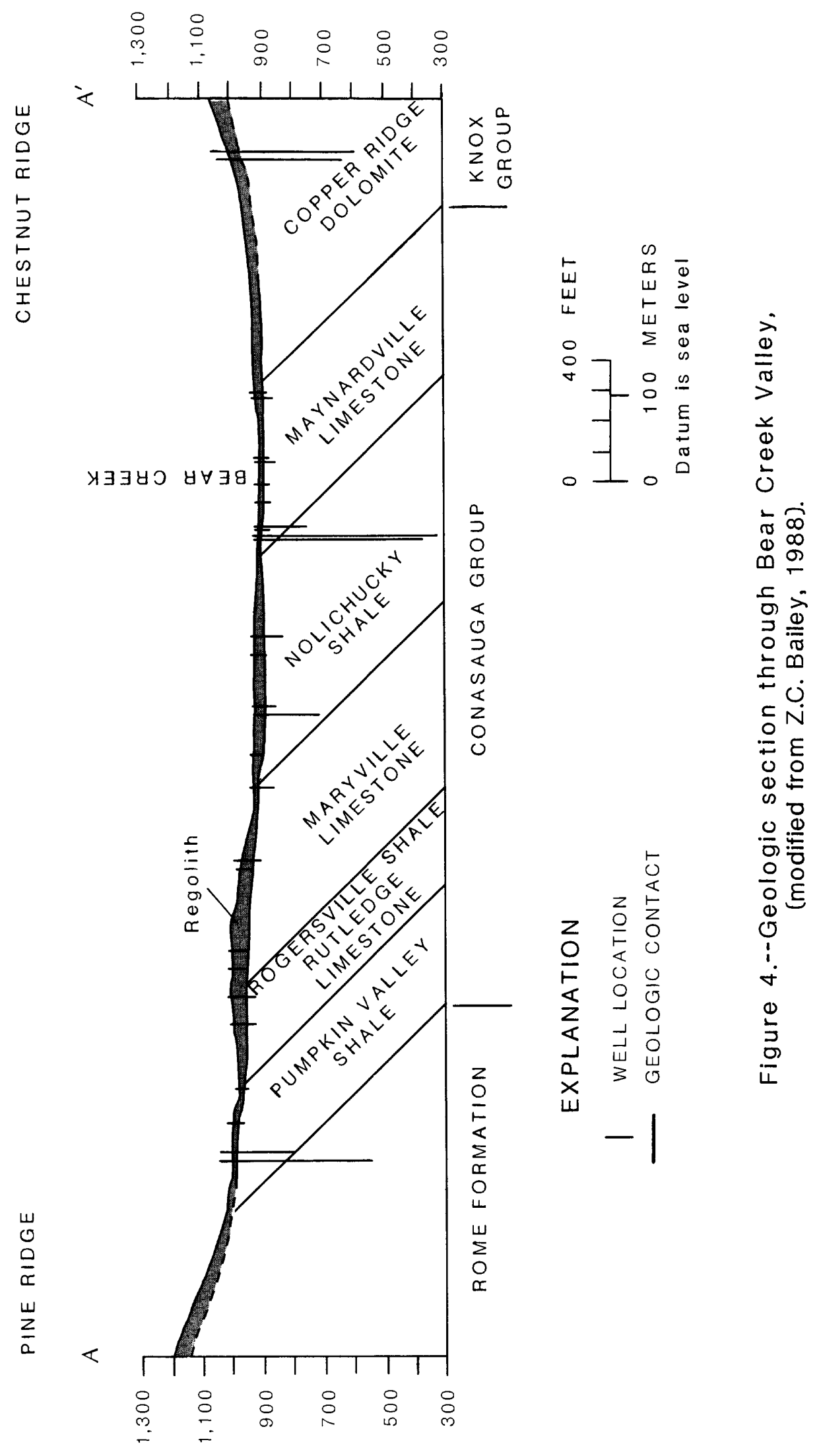




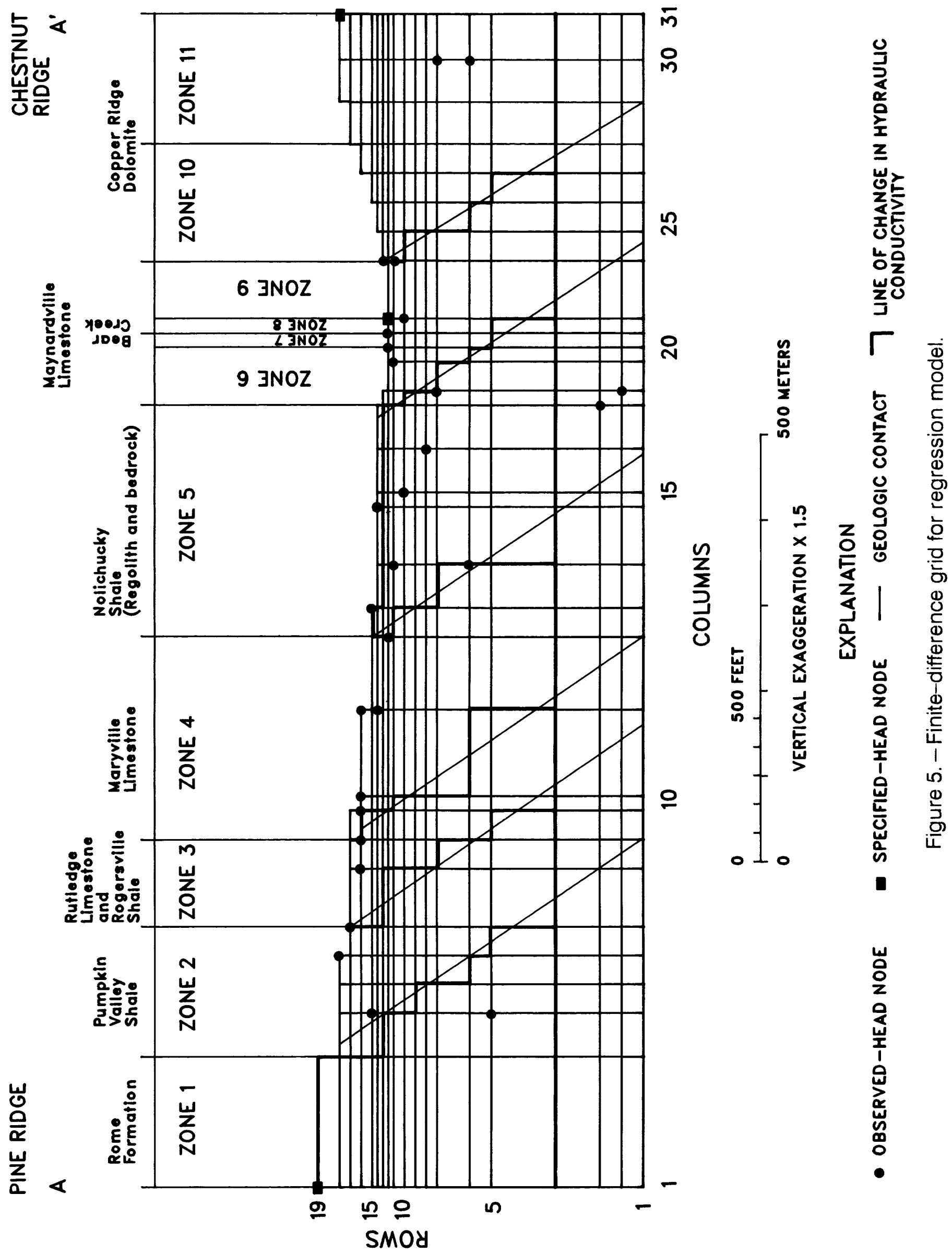




\section{Recharge and Discharge}

The finite-difference model (Bailey, 1988) and preliminary runs of the regression model indicated that all formations are net discharge zones except for the Rome Formation (Pine Ridge) and the Copper Ridge Dolomite (Chestnut Ridge), which are recharge areas, and that the maximum discharge areas occur in the formations immediately adjacent to the recharge areas. Recharge was calculated in the finitedifference model (Bailey, 1988) from constanthead nodes that represented the simulated water table.

Eleven recharge and discharge zones on the land surface were selected for the model (fig. 5). Recharge or discharge was assumed to be uniform on the surface of: the Rome Formation (zone 1), the Pumpkin Valley Shale (zone 2), the Rutledge Limestone and Rogersville Shale (zone 3), the Maryville Limestone (zone 4), and the Nolichucky Shale (zone 5). Discharge in the Maynardville Limestone, where the gradient was steep, was divided into four zones; two 50-foot zones on each side of Bear Creek (zones 7 and 8 ) and two 200-foot zones on each extremity of the formation (zones 6 and 9). The Copper Ridge Dolomite was divided into two zones: a 400-foot zone at the base where net recharge is relatively small (zone 10) and a 450-foot zone on top of the ridge (zone 11).

Initial estimates of recharge rate for the ridge tops were: (1) $25 \mathrm{in} / \mathrm{yr}$ for zone 1 in the Rome Formation and (2) $20 \mathrm{in} / \mathrm{yr}$ for zone 11, the Copper Ridge Dolomite (Bailey, 1988 p. 10). Based on the recharge distribution estimated by the finite-difference model (Bailey, 1988), the recharge rate applied to the lower section of Copper Ridge Dolomite (zone 10) was onefourth of the total recharge on the ridge top divided by the area of zone 10 . These estimates are reasonable for the areas of highest recharge because the average rainfall is $54.45 \mathrm{in} / \mathrm{yr}$, for years 1956 through 1985 (National Oceanic and
Atmospheric Administration, 1985) and evapotranspiration is approximately 20 to 30 in/yr for oak-hickory cover (Lull, 1964), which is the predominant forest type of this area. Direct runoff is assumed to be negligable due to the storage capacity of the regolith on the ridges (McMaster, 1967, p. 13-14).

The following assumptions were used to make initial estimates of discharge rates and to distribute discharge over the discharging zones: (1) the maximum discharge areas occur in the formations immediately adjacent to the recharge areas, (2) Bear Creek represents the groundwater divide between the two ridges, and (3) recharge and discharge volumes balance on each side of Bear Creek. In order to estimate the rates, a water-volume rate was calculated for each recharge zone and distributed to each discharge zone as follows:

1. One-half of the recharge volume from Pine Ridge (the Rome Formation) discharges through the Pumpkin Valley Shale.

2. One-fourth of the recharge volume from Pine Ridge discharges through the Rutledge Limestone and Rogersville Shale.

3. The remaining one-fourth of the recharge volume from Pine Ridge was distributed equally through the remaining four zones to the north of Bear Creek, zones 4 through 7 (fig. 5).

4. One-eighth of the recharge volume from Chestnut Ridge discharges through zone 8 , just south of Bear Creek.

5. Seven-eighths of the recharge volume from Chestnut Ridge discharges through zone 9 , adjacent to the ridge.

The water-volume rate for discharge for each zone was divided by the area of the zone to determine the respective discharge rates. 


\section{Coefficients of Variation}

Coefficients of variation (CV) are used as constraints on the regression model to control the changes in initi:1 estimates of regression parameters. Model estimates of regression parameters can be improved if prior information is known about the parameters. Prior information were available on hydraulic conductivity for all the formations, for the specified head at Bear Creek, and for recharge. This information was used to calculate $\mathrm{CV}$ as follows:

$$
\mathrm{CV}=\frac{\text { Standard Deviation }}{\text { Mean }}
$$

The CV for hydraulic conductivity (table 9) were calculated from the log-transformed data using the transformations given in Viessman and others (1977, p 174).

The mean and standard deviation for the specified-head node near Bear Creek was calculated from available water-level data for a well near Bear Creek. The mean water level for the period April 19, 1984 to December 12, 1985 is 886.4 feet and the standard deviation (SD) is 1.9 feet. The CV is 0.0021 .

Because measured data are not available for the recharge and the specified heads on the ridges, a uniform distribution, which only requires estimates of extremes, was assumed. The $\mathrm{CV}$ can be determined (equation 3 ) from the mean and standard deviation of a uniform distribution calculated as follows (Haan, 1979, p. 97):

$$
\begin{aligned}
\text { Mean } & =\frac{(B+A)}{2} \\
\mathrm{SD} & =\frac{(\mathrm{B}-\mathrm{A})}{\sqrt{12}}
\end{aligned}
$$


Table 10.--Initial recharge and discharge rates and coefficients of variation

\begin{tabular}{|c|c|c|c|c|c|c|c|c|c|}
\hline \multirow[t]{2}{*}{ Zone } & \multirow{2}{*}{$\begin{array}{l}\text { Length, } \\
\text { in feet }\end{array}$} & \multicolumn{2}{|c|}{ Recharge ${ }^{1}$} & \multirow{2}{*}{\multicolumn{2}{|c|}{$\begin{array}{c}\text { Range, in } \\
\text { inches per } \\
\text { year }\end{array}$}} & \multirow{2}{*}{$\begin{array}{c}\text { Difference }{ }^{2} \text {, } \\
\text { in inches per } \\
\text { year }\end{array}$} & \multirow{2}{*}{$\begin{array}{l}\text { Standard } \\
\text { deviation }\end{array}$} & \multirow{2}{*}{$\begin{array}{l}\text { Coefficient } \\
\text { of variation }\end{array}$} & \multirow[t]{2}{*}{ Formation } \\
\hline & & $\begin{array}{l}\text { in feet } \\
\text { per } \\
\text { day }\end{array}$ & $\begin{array}{c}\text { in inches } \\
\text { per } \\
\text { year }\end{array}$ & & & & & & \\
\hline 1 & 450 & 0.0057 & 25.0 & 20 & to 30 & 10.0 & 2.89 & 0.115 & Rome Formation \\
\hline 2 & 450 & -.00285 & -12.5 & -2.5 & to -22.5 & 20.0 & 5.77 & .46 & Pumpkin Valley Shale \\
\hline 3 & 300 & -.00214 & -9.38 & 0 & to -19.4 & 19.4 & 5.58 & .59 & $\begin{array}{l}\text { Rutledge Limestone and } \\
\text { Rogersville Shale. }\end{array}$ \\
\hline 4 & 700 & -.00023 & -1.0 & 0 & to -2 & 2.0 & .58 & .58 & Maryville Limestone \\
\hline 5 & 800 & -.0002 & -.88 & 0 & to -1.8 & 1.8 & .52 & .58 & Nolichucky Shale \\
\hline 6 & 200 & -.0008 & -3.52 & 0 & to -7 & 7.0 & 2.03 & .58 & $\begin{array}{l}\text { Maynardville Limestone } \\
\text { North } 200 \text {-foot section }\end{array}$ \\
\hline 7 & 50 & -.0032 & -14.06 & -4 & to -24 & 20.0 & 5.77 & .41 & $\begin{array}{l}\text { Maynardville Limestone } \\
\text { North } 50 \text {-foot section }\end{array}$ \\
\hline 8 & 50 & -.0064 & -28.12 & .8 & to -48 & 40.0 & 11.55 & .41 & $\begin{array}{l}\text { Maynardville Limestone } \\
\text { South } 50 \text {-foot section }\end{array}$ \\
\hline 9 & 200 & -.011 & -49.3 & -29 & to -69 & 40.0 & 11.55 & .23 & $\begin{array}{l}\text { Maynardville Limestone } \\
\text { South } 200 \text {-foot section }\end{array}$ \\
\hline 10 & 400 & .0013 & 5.7 & 0 & to 12 . & 12.0 & 3.29 & .58 & $\begin{array}{l}\text { Copper Ridge Dolomite } \\
\text { Lower section }\end{array}$ \\
\hline 11 & 450 & .00457 & 20.0 & 15 & to 25 & 10.0 & 2.89 & .144 & $\begin{array}{l}\text { Copper Ridge Dolomite } \\
\text { Upper section }\end{array}$ \\
\hline
\end{tabular}

${ }_{2}^{1}$ Negative indicates discharge.

2 Difference is (B-A), equation 5.

\section{RESULTS OF SIMULATION}

The 11 recharge or discharge zones and the 3 specified boundary heads were regression parameters in all the simulations. Hydraulic heads were specified on the divides and at a water-table well immediately south of Bear Creek (fig. 5). Averages of water levels measured during October 1986 were used as observed hydraulic heads in the regression model. Only the hydraulic-conductivity regression parameters differed in the following three simulations:

Run 1. Each formation and deep bedrock were treated as separate zones and the hydraulic conductivities of the seven formations were regression parameters.

Run 2. Same as Run 1 except that hydraulic conductivity of the deep bedrock was also treated as a regression parameter.

Run 3. Same as Run 1 except the Nolichucky Shale regolith was treated as a separate zone and its hydraulic conductivity, a regression parameter.

Because initial estimates, $\mathrm{CV}$, and model assumptions were based on abundant data and previous modeling, repeated adjustments in individual regression parameters (a standard calibration procedure in finite-difference 
modeling), which would reduce overall model error, were not done. That type of calibration process would have resulted in lower model error, but might also have caused serious deviation from real data that represented the real flow system. The results of each of the three model runs did not mask any data deficiencies. This approach allowed identification of areas where additional data would be needed to improve the understanding of the flow system.

Statistical results for the three simulations are presented in table 11, and initial and modelcalculated regression parameters are compared in table 12.

\section{Model Fit and Conditioning}

In order to evaluate the fit and conditioning of the regression model, two criteria must be considered: (1) how well the calculated heads match the observed heads, and (2) whether the regression parameters are uncorrelated and the residuals are normally distributed.

The results of Run 2, in which deepbedrock hydraulic conductivity is a regression parameter, and Run 1, deep bedrock is not a regression parameter, were identical (table 12), which indicates that deep bedrock is not important to the flow described by this model. Results of Run 3, in which the hydraulic conductivity of the Nolichucky Shale regolith is a separate regression parameter, were very similar to the other runs except for hydraulic-conductivity values for the Nolichucky Shale. However, because the Nolichucky Shale regolith is only a very small part of the modeled area (fig. 5), the results of Run 3 are also similar to Run 2. Consequently, all subsequent discussion is based on results of Run 2, which essentially represents results of all the simulations.

Table 11.--Statistical results of regression model

\begin{tabular}{|c|c|c|c|}
\hline & Run 1 & Run 2 & Run 3 \\
\hline Error variance, in square feet $\left(s^{2}\right)$ & 10.32 & 10.21 & 8.46 \\
\hline $\begin{array}{l}\text { Standard error of estimate } \\
\text { for heads, in feet (s). }\end{array}$ & 3.21 & 3.21 & 2.91 \\
\hline Maximum range in heads, in feet ( $d h$ ) & 150.0 & 150.0 & 150.0 \\
\hline $\mathrm{s} / \mathrm{dh}$ & .021 & .021 & .019 \\
\hline $\begin{array}{l}\text { Correlation between observed } \\
\text { and calculated head }(r) \text {. }\end{array}$ & .9976 & .9976 & .9982 \\
\hline $\begin{array}{l}\text { Maximum correlation between } \\
\text { any two regression parameters }(r) \text {. }\end{array}$ & .8398 & .8398 & .8590 \\
\hline $\begin{array}{l}\text { Percent error in mass balance } \\
\text { for regression models. }\end{array}$ & 4.5 & 4.5 & 5.0 \\
\hline
\end{tabular}


Table 12.--Initial and regression estimates of regression parameters

[-- indicates no estimates made]

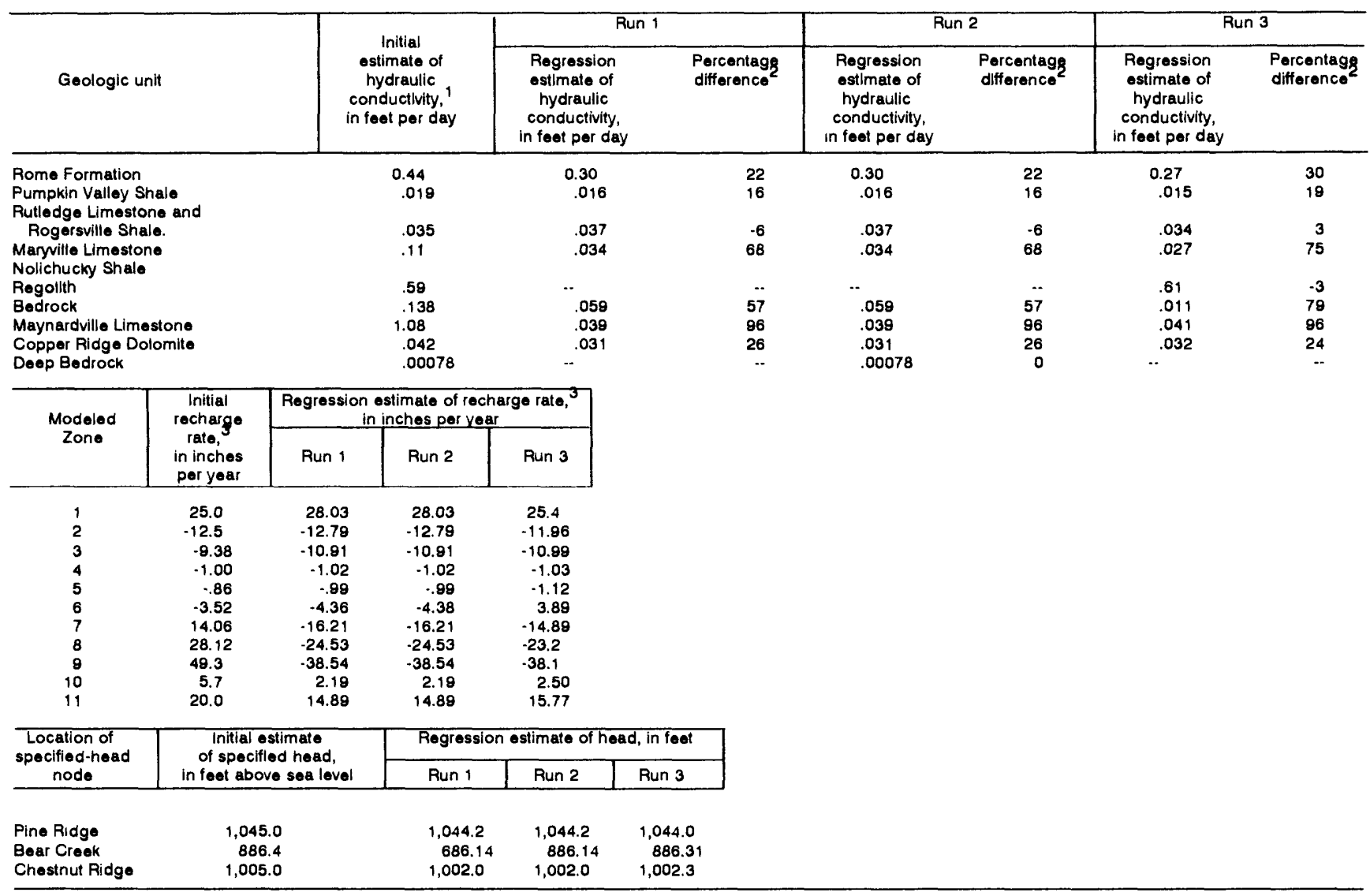

1 Initial estimates of hydraulic conductivities are median vaiues from table 9

2 Percentage difference $=[$ (simulated value - initial value)/initial value] $\times 100$. Negative value indicates regression estimate is greater than the initial estimate.

3 Negative indicates discharge.

The correlation coefficient $(r>0.99)$ between the observed heads and model-calculated heads (table 11) indicates that they are well matched. The ratio of the standard error of estimate for heads to maximum difference in observed heads $(\mathrm{s} / \mathrm{dh})$ is 0.021 , which indicates the fit is fairly good (Cooley and Naff, 1985, p. 420). Consequently, the model fits the data reasonably well.

The model calculated 231 correlation coefficients for combinations of the 22 regression parameters. Of these 231 coefficients, only 4 were high and range from 0.71 to 0.84 (table 11). Therefore, overall, the regression parameters are uncorrelated and the first criteria of model conditioning is satisfied, which indicates that the regression parameters were not generally overconstrained. The regression parameters having high coefficients were not combined because at least one value of hydraulic conductivity was part of each correlation. The conductivity values were kept separate in the simulations to allow a clearer interpretation of the sensitivity of the model to hydraulic conductivity.

Lilliefors test for normality (Iman and Conover,1983, p. 370-383) was used on the standardized residuals. All the values were within the 95-percent bounds, which indicates that the 
residuals are normally distributed. The three lowest residuals are from three of the four deepest wells, which indicates that the model underestimates water levels in the deep wells. A possible explanation is that the water levels in the deep wells are being affected by localized conditions such as water movement along bedding planes, and consequently the water levels do not fit the regional potentiometric surface and cannot be accurately simulated in a regional model. However, the generally normal distribution of the residuals satisfies the second criteria for model conditioning.

Model fit and conditioning were considered to be acceptable because (1) the heads estimated by the model match the observed heads very well; and (2) the model satisfies the assumption of linear independence of the regression parameters, and the residuals are normally distributed.

\section{Model Results and Additional Data Needs}

Initial and regression estimates of hydraulic conductivity and recharge, and the respective initial and model-calculated $C V$ were used to assist in interpretation of the groundwater flow system and to identify areas that require additional data. The three boundary-head regression parameters are not discussed because there was high confidence in the estimates and the $\mathrm{CV}$ were several orders of magnitude lower than the $\mathrm{CV}$ for other groups of parameters.

In general, the regression estimates were lower than the initial estimates of hydraulic conductivity (fig. 6). The largest differences are associated with the formations that have a relatively flat land surface (figs. 4-5) and lower crosssectional hydraulic gradients, the Maryville Limestone, Nolichucky Shale and the Maynardville Limestone. Because the single-well aquifer tests only provide an average hydraulic conduc- tivity for both principal flow directions, the lower regression estimate may indicate that there is flow parallel to strike, which could be a result of an anisotropic medium that has greater permeability in the direction parallel to strike. That component of flow could not be simulated by the model. The lower estimate may also be due to localized aquifer conditions related to fractures and cavities in the Maynardville Limestone, which would cause poor model-calculated estimates of hydraulic conductivity.

Initial and regression estimates of total recharge for each zone were calculated using recharge rate (table 12) and length of the zone (table 10). A 4.5-percent error in mass balance occurred in the regression model (table 11). Recharge rates are calculated as secondary quantities from heads predicted by the model. Because recharge is not solved directly, some error is expected in these secondary calculations. Generally, the regression estimates of total recharge for each zone are similar to the initial estimates on the Pine Ridge side of Bear Creek. Considerable difference (fig. 7) occurred between the regression estimate and initial estimate of total recharge for three of the four zones on the Chestnut Ridge side of Bear Creek. This difference indicates that more data are needed to better define the recharge and discharge zones on the Chestnut Ridge side of Bear Creek.

On the Pine Ridge side of Bear Creek, regression estimates of the volume rate of recharge for each zone are similar to the initial estimates (fig. 7). On the Chestnut Ridge side of Bear Creek, regression estimates of the volume rate of recharge for zones 10 and 11 are considerably less than the initial estimates. The regression estimate of the volume rate of discharge from zone 9 is considerably greater than the initial estimate (fig. 7). This difference indicates that more information is needed to better define the recharge and discharge zones on the Chestnut Ridge side of Bear Creek. 


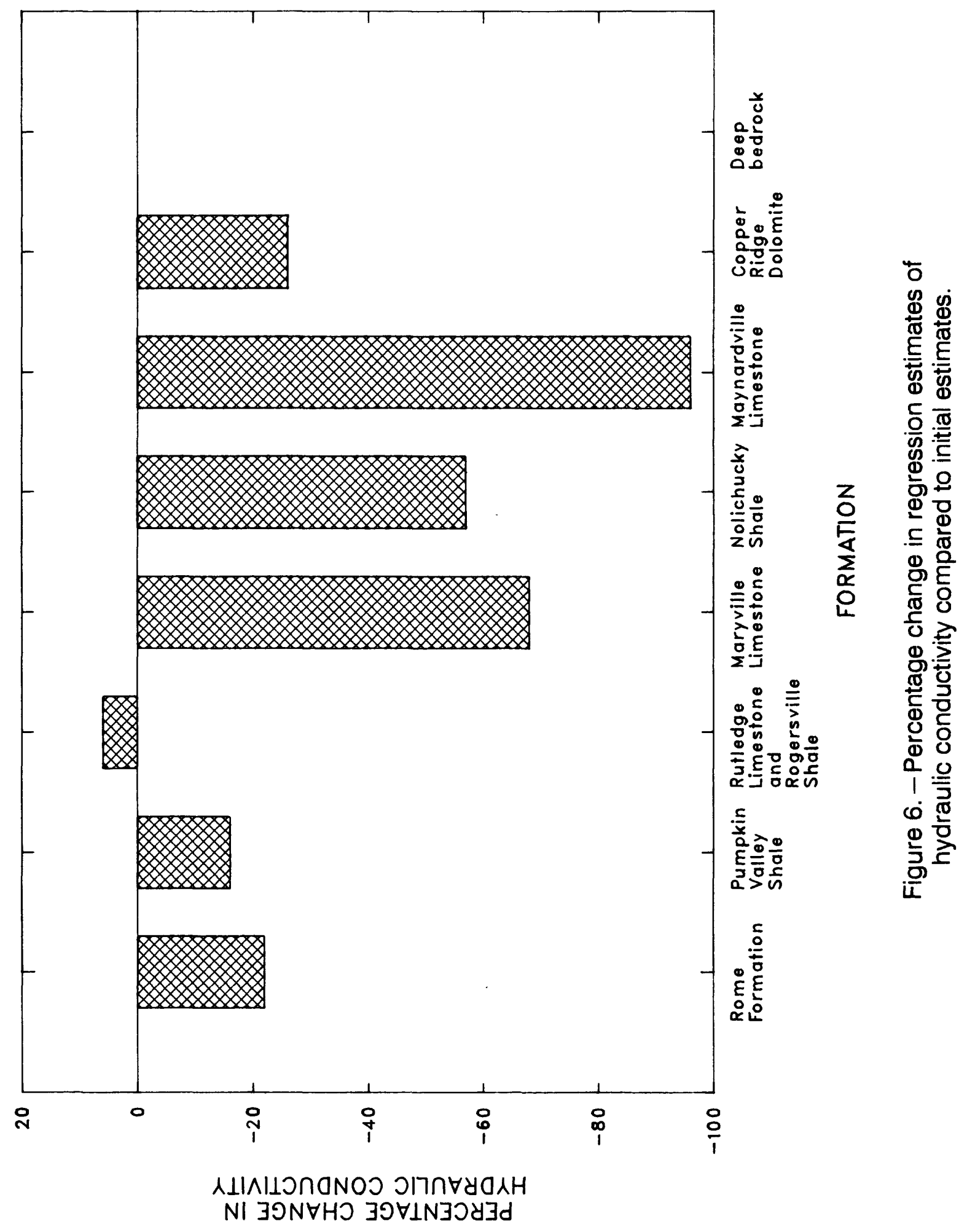




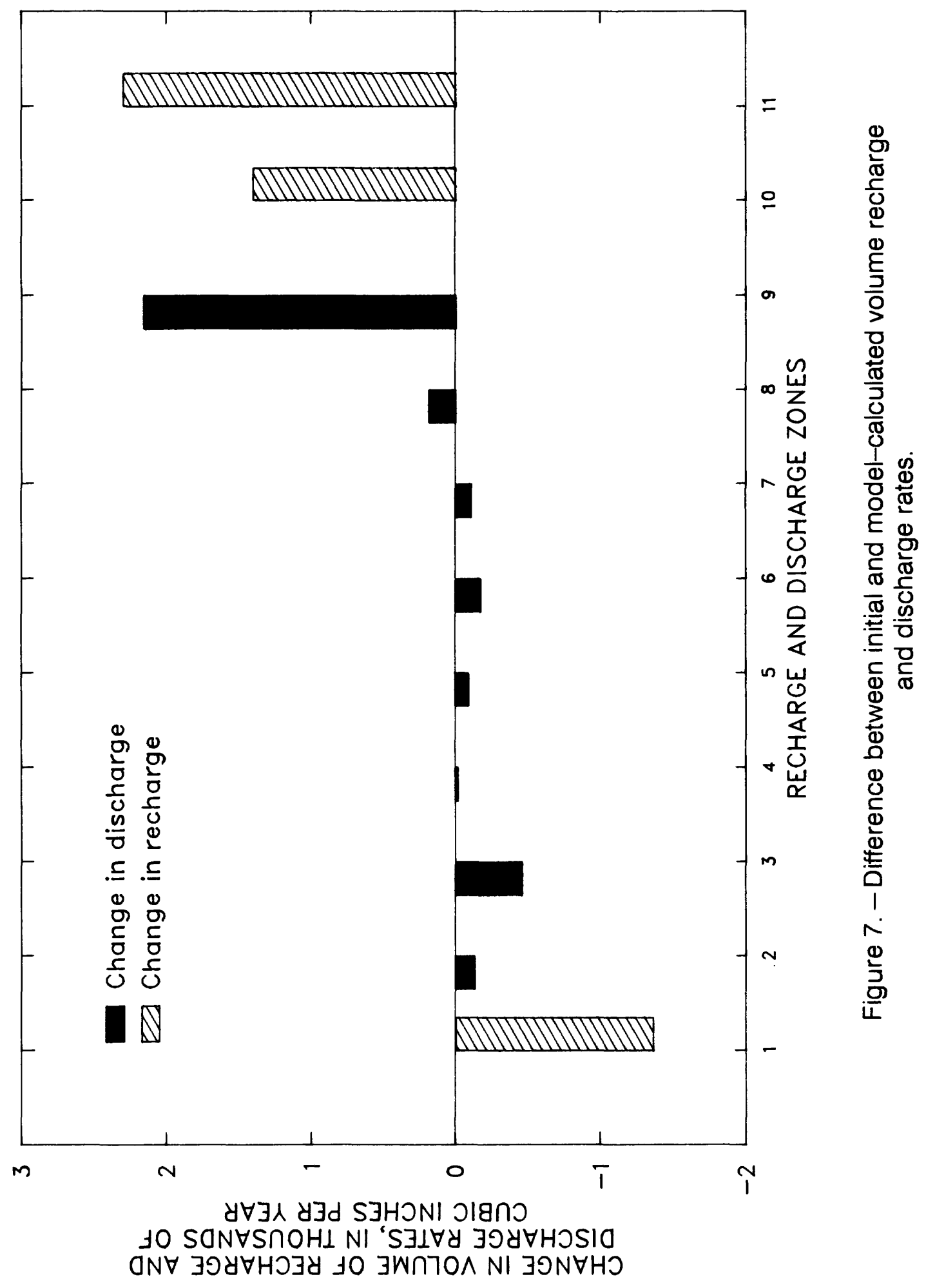


Model simulation may be improved either by improving the initial estimates of regression parameters or by collecting additional waterlevel data, which would constrain the model solution. A large model-calculated $\mathrm{CV}$ suggests that additional water-level data are needed to better define the model in a particular formation or zone. A large initial estimate of $\mathrm{CV}$ for either hydraulic conductivity or recharge suggests that model performance could be improved by having an improved initial estimate of $\mathrm{CV}$, which requires the respective additional field data. To determine what type of additional data were needed, both initial and model-calculated CV were compared for hydraulic conductivity of each formation (fig. 8) and for recharge zones (fig. 9).

The initial estimate of the CV for hydraulic conductivity of the Copper Ridge Dolomite was over two times greater than the initial estimate for the other formations (fig. 8). This difference suggests that additional hydraulic-conductivity data are needed for this formation. The modelcalculated estimate of CV for hydraulic conductivities for each formation were similar, and a need for additional water-level data in any particular formation could not be determined.

Initial estimates of $\mathrm{CV}$ for the principal recharge zones ( 1 and 11 ) were relatively similar (fig. 9), which indicates that recharge information was sufficient to simulate the flow system. Collection of additional recharge information would not improve simulations as much as collection of other types of data. The discharge zones and zone 10 have similar initial estimates of $\mathrm{CV}$ although they are higher than estimates for the two recharge zones. This difference is due to lower confidence in the discharge estimates. Model-calculated estimates of $\mathrm{CV}$ for each recharge zone were similar except for zone 10 (fig. 9) on Chestnut Ridge. The difference indicates that more water-level data are needed for the Copper Ridge Dolomite, particularly for zone 10 .

\section{Sensitivity}

Sensitivities from the regression model were used to demonstrate responses of the model to changes in hydraulic conductivity and recharge (Cooley and Naff, 1985), and to assist in interpretation of the ground-water flow system.

The scaled sensitivity (SW) for regression parameter $A_{m}$ is defined as:

$$
\mathrm{SW}=\frac{\mathrm{dH}_{\mathrm{i}}}{\mathrm{dA_{ \textrm {m } }}}\left(\mathrm{A}_{\mathrm{m}}\right)
$$

where

$\mathrm{H}_{\mathrm{i}}$ is the head at location (i), and

$A_{m}$ is the value of regression parameter (m).

If an increase in the hydraulic conductivity in a formation results in increases in the heads of the downgradient formations, this indicates that the upgradient formation is acting as a control on downgradient ground-water flow. The relative magnitude of head increase in the downgradient formation indicates the importance of that control.

Increases in hydraulic conductivity of the Rome Formation, the Pumpkin Valley Shale, and the Rutledge Limestone and Rogersville Shale cause positive changes in all downgradient formations (fig. 10). This indicates that these three formations control downgradient flow and the amount of ground water reaching downgradient formations.

Overall model sensitivity to the hydraulic conductivity of the Pumpkin Valley Shale is over twice that of any other unit. The sensitivities are positive, except for the Rome Formation, which is upgradient. An increase in hydraulic conductivity in the Pumpkin Valley Shale, which causes large increases in heads in the downgradient formations, suggests that the Pumpkin Valley Shale is the formation that primarily controls the downgradient flow from the Pine Ridge recharge area (fig. 10). 


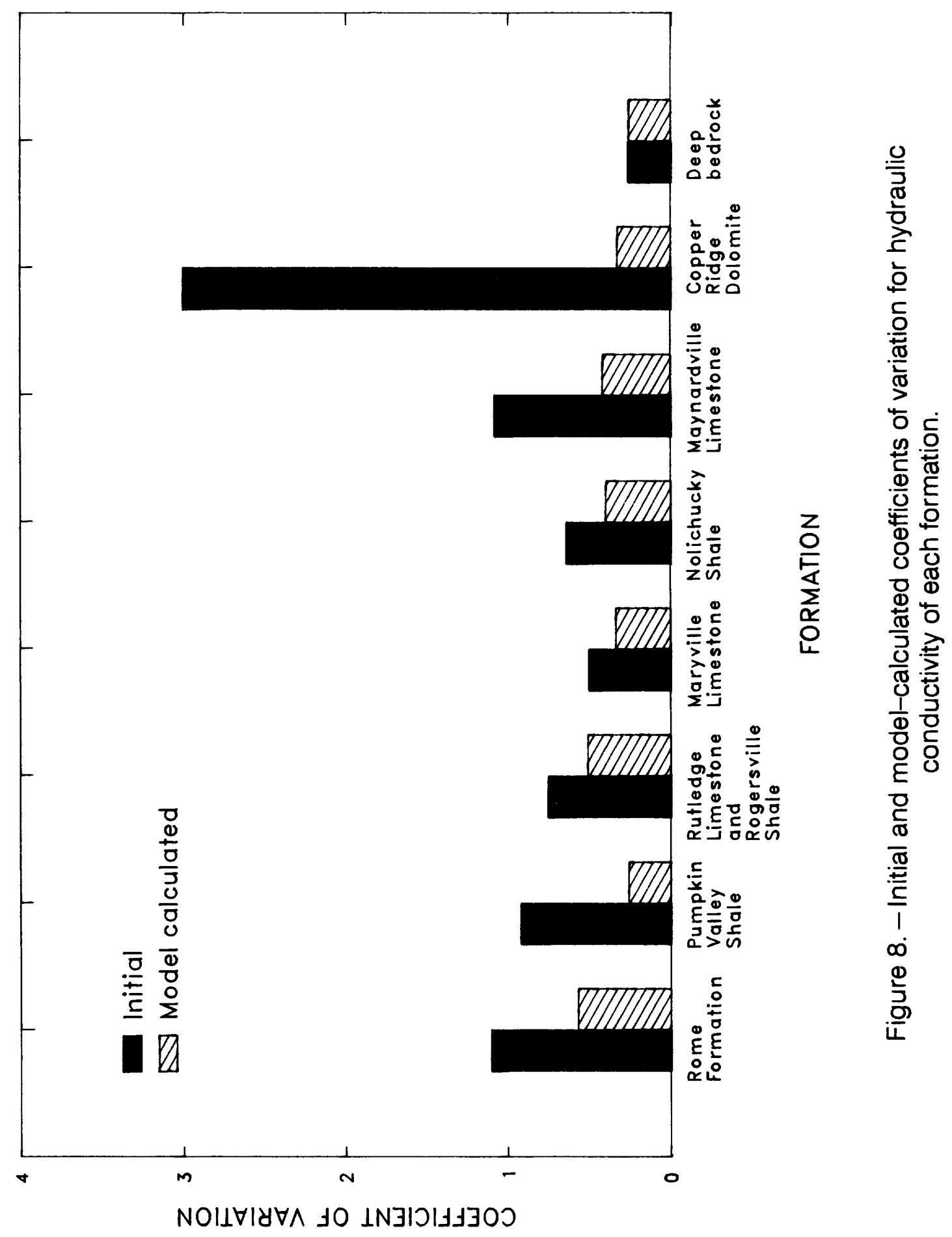




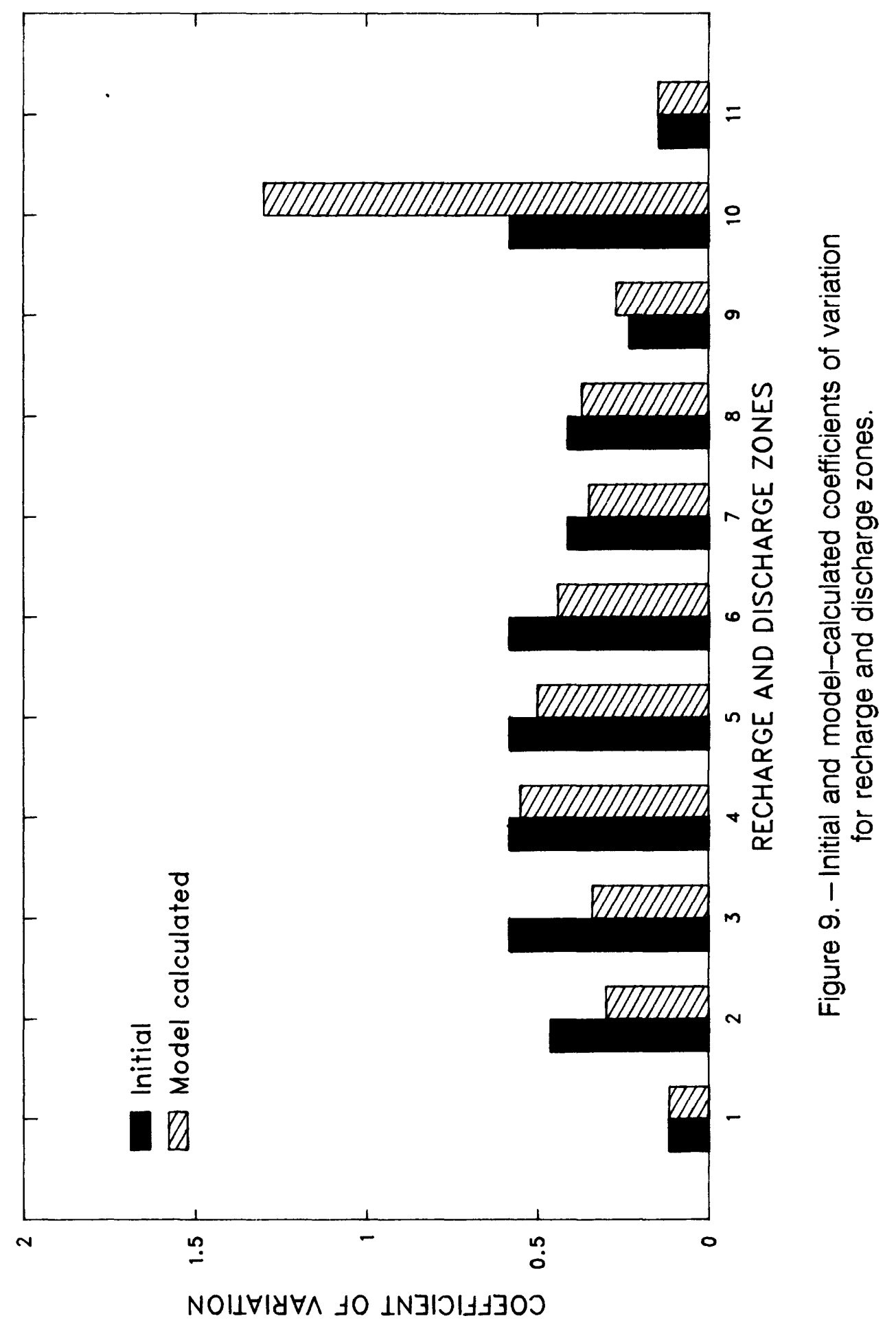


An increase in hydraulic conductivity in the Maynardville Limestone causes an decrease in heads in all formations, indicating that the Maynardville Limestone is receiving water from all formations (fig. 10.)

The model is almost two orders of magnitude less sensitive to the hydraulic conductivity in deep bedrock than other regression parameters. Treating deep bedrock as a regression parameter does not affect the results of the model (fig. 10).

On the Pine Ridge side of Bear Creek, the model is very sensitive to increased discharge from the Pumpkin Valley Shale and the Rutledge Limestone and Rogersville Shale (fig. 11), which suggests that these formations are the primary discharge areas on that side of Bear Creek. This discharge may be in the form of depression springs in areas dissected by stream channels (Exxon Nuclear Company, Inc., 1978, p. 3.5-10). The model is relatively insensitive to the remaining zones on that side, which suggests that relatively small amounts of water are being discharged through the remaining zones on the Pine Ridge side of Bear Creek.

On the Chestnut Ridge side of Bear Creek, the model is very sensitive to a change in recharge on the crest of the ridge (zone 11); however, it is relatively insensitive to a change in recharge on the downslope zone, zone 10 , of the Copper Ridge Dolomite. This difference in sensitivity suggests that zone 10 also contains comparable discharge areas (fig. 10) and zone 11 is the primary recharge zone on the Chestnut Ridge side of Bear Creek.

The model is an order of magnitude more sensitive to discharge through the 200 -foot section of the Maynardville Limestone adjacent to the Copper Ridge Dolomite, zone 9, than the other discharging zones in the Maynardville Limestone (fig. 11). This indicates that zone 9 is the primary discharge zone in the Maynardville
Limestone. This discharge is often in the form of springs.

\section{CONCLUSIONS}

A total of 338 single-well aquifer tests from Bear Creek and Melton Valleys were selected and statistically grouped to estimate representative hydraulic-conductivity values for each geologic formation, for regolith of each formation, and for deep bedrock. Hydraulic conductivities were greater in the regolith than the bedrock in all formations except those of the Knox Group. The difference between regolith and bedrock hydraulic conductivity was more apparent in Melton Valley than Bear Creek Valley, particularly in the Maryville Limestone. Regolith and bedrock conductivity values could be aggregated for each formation in Bear Creek Valley except the Nolichucky Shale, and for all formations in Melton Valley except the Maryville Limestone. Bedrock deeper than 400 feet below land surface could be treated separately due to conductivity values orders of magnitude smaller than those for shallower bedrock.

A cross-sectional simulation model linked to a regression model was constructed to further refine the statistical estimates of hydraulic conductivity and to better understand the mechanisms of ground-water flow in Bear Creek Valley. Median values determined for the geologic groups in Bear Creek Valley were used as initial values in the model.

Model estimates were generally lower than the statistical estimates of hydraulic conductivity, particularly in formations having a smaller hydraulic gradient. This difference may suggest that hydraulic conductivity is greater parallel to strike than perpendicular to strike, or that the single-well aquifer tests were often affected by fractures or cavities, which represent very local hydraulic conditions. Hydraulic-conductivity values from tests in the Maynardville Limestone 


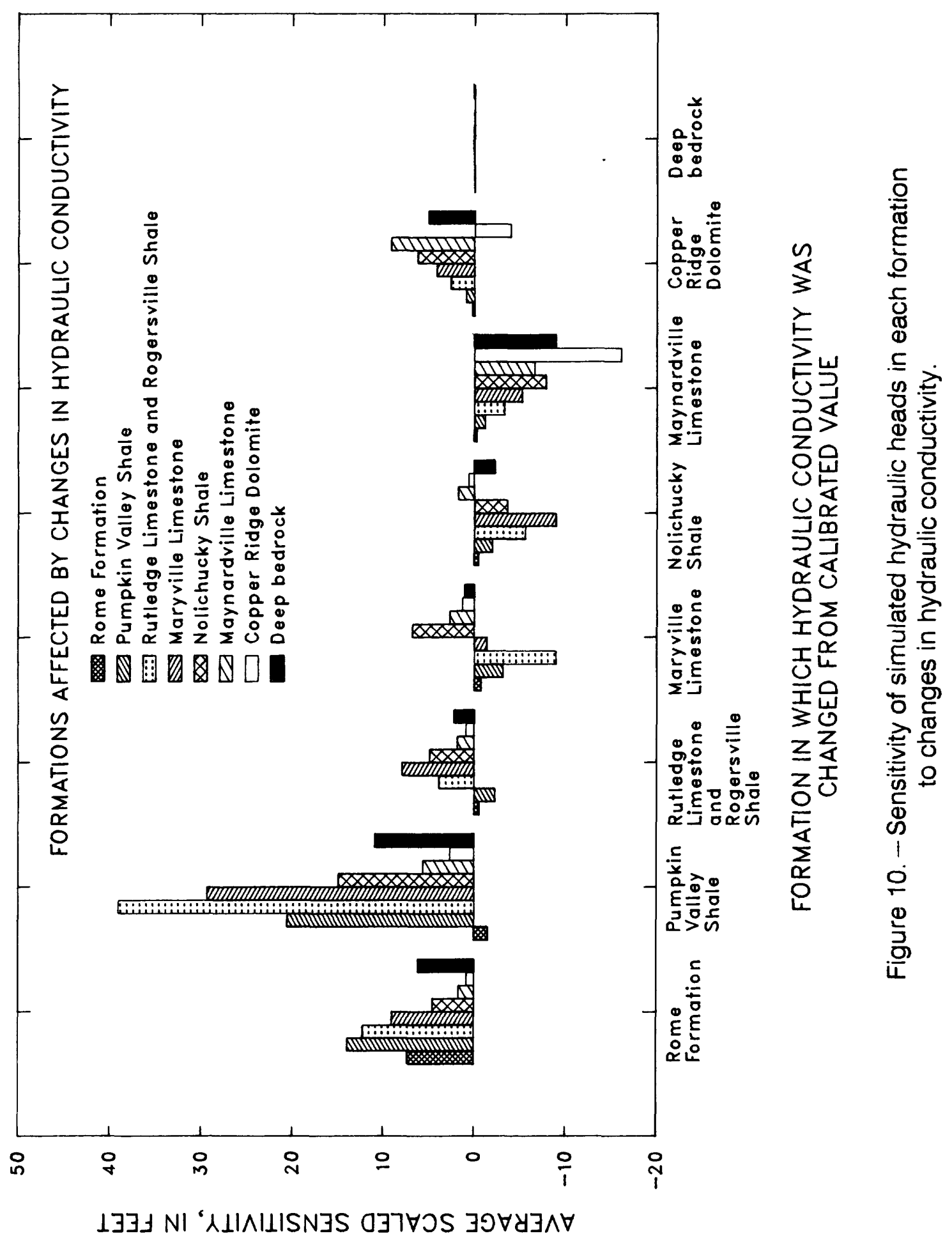




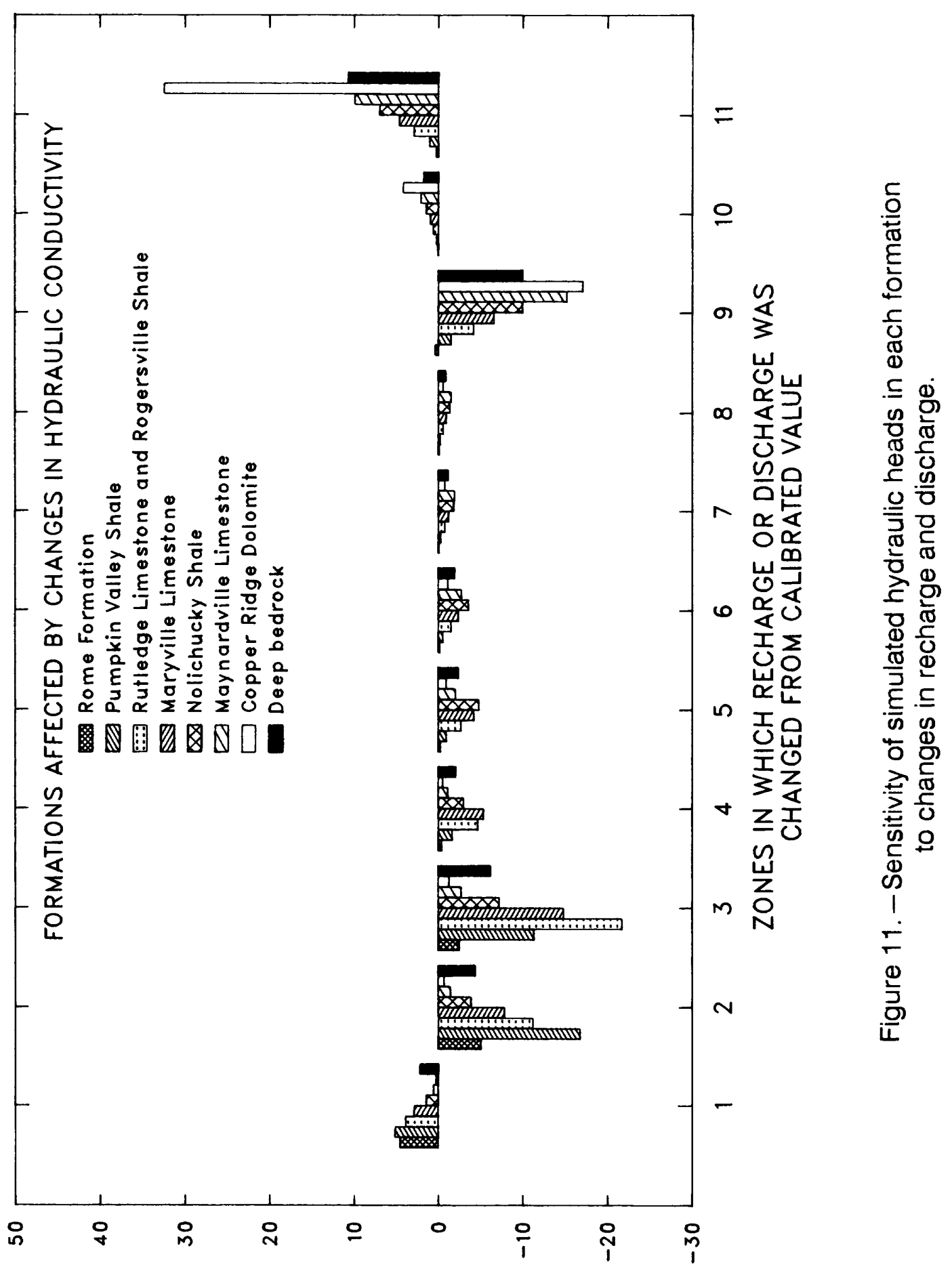

$1 \exists \exists \unlhd \mathrm{NI}$ ' $\wedge \perp$ IISN 
are large in comparison to those from other formations in the study area, because locally this formation contains cavities. Aquifer tests affected by cavities may reflect local hydraulic conductivities but can overestimate regional hydraulic conductivities.

Overall, simulated heads matched observed heads very well except for deep wells. Water levels from wells in the deep bedrock are probably influenced by weathering along bedding planes, are not representative of the regional potentiometric surface, and consequently, cannot be accurately simulated by this model.

Model results indicate that initial estimates of recharge and hydraulic conductivity were probably more accurate on the Pine Ridge side of Bear Creek than on the Chestnut Ridge side. The Pumpkin Valley Shale is the formation that controls ground-water flow on the Pine
Ridge side of Bear Creek. Only a small amount of the ground water from Pine Ridge reaches the Maynardville Limestone, and most of the discharge occurs in the Pumpkin Valley Shale and the Rutledge Limestone and Rogersville Shale. Most of the recharge to the Maynardville Limestone comes from near the crest of Chestnut Ridge in the Copper Ridge Dolomite, and is primarily discharged through a 200 -foot zone in the Maynardville Limestone at the base of Chestnut Ridge.

Refinements in the model and a better understanding of ground-water flow would require the following data: (1) water levels from additional wells in the Copper Ridge Dolomite, particularly in the downslope zone, zone 10; (2) additional aquifer tests in the Copper Ridge Dolomite and the Maynardville Limestone in sections of rock that would not be influenced by cavities; and (3) water levels and aquifer test in additional wells in deep bedrock. 


\section{REFERENCES CITED}

Bailey, Z.C., 1988, Preliminary evaluation of ground-water flow in Bear Creek Valley, the Oak Ridge Reservation, Tennessee: U.S. Geological Survey Water-Resources Investigations Report 88-4010, $12 \mathrm{p}$.

Bechtel National Inc., 1984a, The geology and hydrogeology of Bear Creek Valley Waste Disposal Areas A and B: Oak Ridge, Tennessee, U.S. Department of Energy, Oak Ridge Y-12 Plant, Y/SUB/84-47974C/3, $22 \mathrm{p}$.

-----1984b, Interim report on Bear Creek Valley Oil Landfarm geology and hydrogeology: Oak Ridge, Tennessee, U.S. Department of Energy, Oak Ridge Y-12 Plant, Y/SUB/84-47974C/1, $20 \mathrm{p}$.

-----1984c, Interim report on the geology and hydrogeology of the southern and western perimeter to the burial grounds and the interior portions of Bear Creek Valley Waste Disposal Areas: Environmental field studies: Oak Ridge, Tennessee, U.S. Department of Energy, Oak Ridge Y-12 Plant, Y/SUB/84-47974C/4, $21 \mathrm{p}$.

Conover, W.J., 1980, Practical nonparametric statistics ( $2 \mathrm{~d}$ ed.): New York, John Wiley and Sons, $493 \mathrm{p}$.

Cooley, R.L., and Naff, R.L., 1985, Regression modeling of ground-water flow: U.S. Geological Survey Open-File Report 85-180, $450 \mathrm{p}$.

Exxon Nuclear Company, Inc., 1978, Nuclear fuel recovery and recycling center: Preliminary safety analysis report: Exxon Nuclear Company, Inc., Docket 50-564, Chapters 1-3.

Freeze, R.A., 1975, A stochastic-conceptual analysis of one-dimensional groundwater flow in nonuniform homogeneous media: Water Resources Research, v. 11, no. 5, p. 725-741.

Geraghty \& Miller, Inc., 1987, Preliminary evaluation of the hydrogeologic and waterquality data from phase 4 wells located in the Bear Creek Valley Waste Disposal Area for the period summer 1985-September 1986: Oak Ridge, Tennessee, U.S. Department of Energy, Oak Ridge Y-12 Plant, Y/Sub/85-00206C/9.

Haan, C.T., 1979, Statistical methods in hydrology ( $2 \mathrm{~d}$ ed.): Ames, Iowa, Iowa State University Press, $378 \mathrm{p}$.

Haase, C.S., Walls, E.C., and Farmer, C.D., 1985, Stratigraphic and structural data for the Conasauga Groups and Rome Formation on the Copper Creek Fault Block near Oak Ridge, Tennessee: Preliminary results for test borehole ORNL-JOY No. 2: Oak Ridge National Laboratory, Environmental Sciences Division Publication No. 2392, ORNL/TM-9159, $88 \mathrm{p}$.

Haase, C.S., Zucker, C.L., and Stow, S.H., 1985, Geology of the host formation for the new hydraulic fracturing facility at Oak Ridge National Laboratory, in Post, R.G., and Wacks, M.E., eds., Proceedings of Waste Management 85: Tucson, Arizona, University of Arizona, v. 2, p. 473-480.

Hoos, A.B., and Bailey, Z.C., 1986, Reconnaissance of surficial geology, regolith thickness, and configuration of the bedrock surface in Bear Creek and Union Valleys, near Oak Ridge, Tennessee: U.S. Geological Survey Water-Resources Investigations Report 86-4165, 9 p. and 1 pl.

Iman, R.L., and Conover, W.J., 1983, A modern approach to statistics: New York, John Wiley \& Sons, $497 \mathrm{p}$.

Ketelle, R.H., and Huff, D.D., 1984, Site characterization of the West Chestnut Ridge site: U.S. Department of Energy, Oak Ridge National Laboratory, Environmental Sciences Division, ORNL/TM-9229, $137 \mathrm{p}$.

Lull, H.W., 1964, Ecological and silvaculture aspects: Section 6, in Chow, V.T., Handbook of Applied Hydrology: New York, McGraw-Hill, Inc., 30 p. 
McMaster, W.M., 1963, Geologic map of the Oak Ridge Reservation, Tennessee: Oak Ridge Tennessee, U.S. Atomic Energy Commission, Oak Ridge National Laboratory, ORNL/TM-713, $23 \mathrm{p}$.

----1967, Hydrologic data for the Oak Ridge area, Tennessee: U.S. Geological Survey Water-Supply Paper 1839-N, 60 p.

National Oceanic and Atmospheric Administration, 1985, Local climatological data, annual summary with comparative data, Oak Ridge, Tennessee: Ashville, N.C. U.S. Department of Commerce, National Climatic Data Center, 8 p.

Rothschild, E.R., Huff, D.D., Haase, C.S., Clapp, R.B., Spalding, B.P., Farmer, C.D., and Farrow, N.D., 1984a, Geohydrologic characterization of proposed solid waste storage area (SWSA) 7: U.S. Department of Energy, Oak Ridge National Laboratory, Environmental Sciences Division Publication no. 2380, ORNL/TM-9314, 262 p.

Rothschild, E.R., Turner, R.R., Stow, S.H., Bogle, M.A., Hyder, L.K., Sealand, O.M., and Wyrick, H.J., 1984b, Investigation of subsurface mercury at the Oak Ridge Y-12 Plant: U.S. Department of Energy, Oak Ridge National Laboratory, Environmental Sciences Division Publication no. 2399, ORNL/TM-9092, $258 \mathrm{p}$.

Tucci, Patrick, 1986, Ground-water flow in Melton Valley, Oak Ridge Reservation, Roane County, Tennessee--Preliminary model analysis: U.S. Geological Survey WaterResources Investigations Report 85-4221, $20 \mathrm{p}$.

Tufte, E.R., 1983, The visual display of quantitative information: Cheshire, Connecticut, Graphics Press, $197 \mathrm{p}$.

Viessman, W., Harbaugh, T.E., and Knapp, J.W., 1977, Introduction to hydrology: New York, Intext Educational Publishers, 704 p. Woodward-Clyde Consultants, 1984, Appendices, Subsurface characterization and geohydrologic site evaluation, West Chestnut Ridge site: Oak Ridge, Tennessee, U.S. 


\section{APPENDIX A} 1977):

The plotting positions of the ranked data were determined by the Weibull formula (Viessman,

$$
\operatorname{Prank}=\left[1-\left(\frac{\mathrm{m}}{(\mathrm{n}+1)}\right)\right](
$$

where

Prank is the probability of a value being equal to or greater than the ranked value,

$\mathrm{m}$ is the rank of increasing values, and

$\mathrm{n}$ is the number of values.

The exceedance probability, which corresponded to different plotting positions, was used as the $\mathrm{x}$-axis label for the graphs in Appendix B.

The standard deviate for each plotting position (Zrank) was estimated as follows:

1. The standard deviate was determined from the hydraulic-conductivity data for each data point as follows:

$$
\text { Zest }=\frac{(\mathrm{Xi}-\mathrm{X})}{\mathrm{S}}
$$

where

$\mathrm{Xi}$ is the data point,

$\mathrm{X}$ is the mean,

$\mathrm{S}$ is the standard deviation, and

Zest is the standard deviate associated with $\mathrm{Xi}$.

This value (Zest) was used for the initial guess of the standard deviate of the rank (Zrank).

2. Negative infinity was assumed to be negative for standard deviates which correspond to an area less than $1 / 10,000$ or an exceedance greater than 0.99999 . The probability density function (PDF) for the standard normal distribution was integrated using Simpson's rule, with 20 divisions as follows:

$$
\text { Pest }=\frac{f(z) d z=h[f(-4)+4 f(h-4)+2 f(2 h-4)+4 f(3 h-4)+2 h(4 h-4)+\ldots+4 f(19 h-4)+f(z e s t)}{3}
$$

where

Pest is the calculated probability

$$
\mathrm{h}=\frac{(\text { Zest }+4)}{20}
$$




$$
\begin{aligned}
& f(z)=\frac{1}{2} e^{-(z e s t / 2)} \\
& z(i)=-4+(i)(h)
\end{aligned}
$$

3. Taylor expansion is used to estimate the standard deviate of the plotting position (Zrank) as follows by expanding the cumulative distribution function (CDF) about the point Zest and neglecting second order terms as follows:

$$
\text { Prank }=\text { Pest }+[\mathrm{f}(\text { Zest })](\text { Zrank }- \text { Zest })
$$

Then Equation (1) is solved for Zrank:

$$
\text { Zrank }=\text { Zest }+\frac{(\text { Prank }- \text { Pest })}{\mathrm{f}(\text { Zest })}
$$

The calculated probability (Pest) is compared to the probability associated with the plotting position (Prank). If the difference was less than an acceptable error then the estimated standard deviate (Zrank) from equation (2) was used for the plotting position. If not, then this procedure is repeated using the approximate Zrank from equation (2) as the new Zest. 


\section{APPENDIX B}

Log-Pearson Type III Frequency Plots of Hydraulic-Conductivity Data 

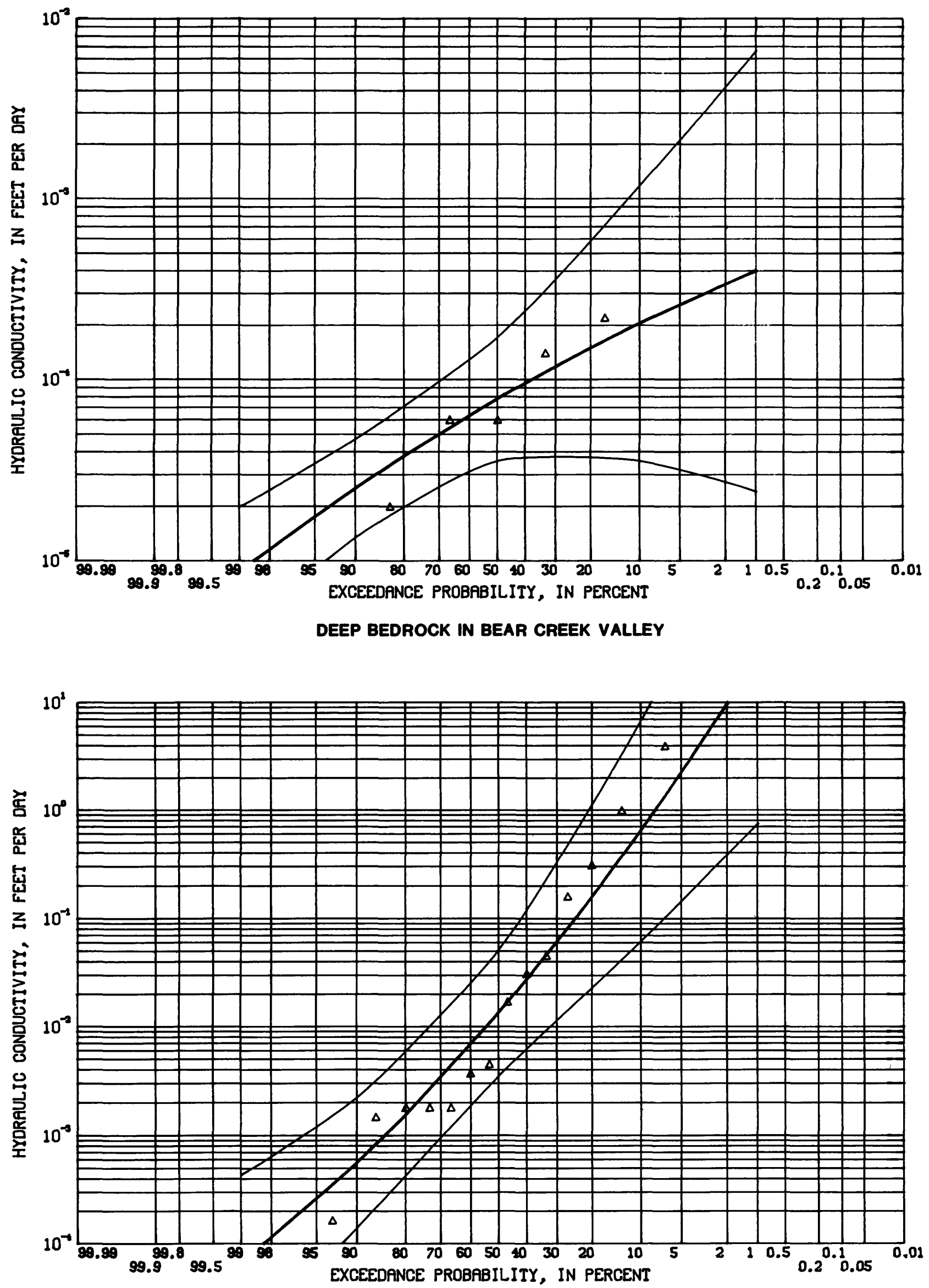

CHEPULTEPEC DOLOMITE (BEDROCK) IN BEAR CREEK VALLEY 


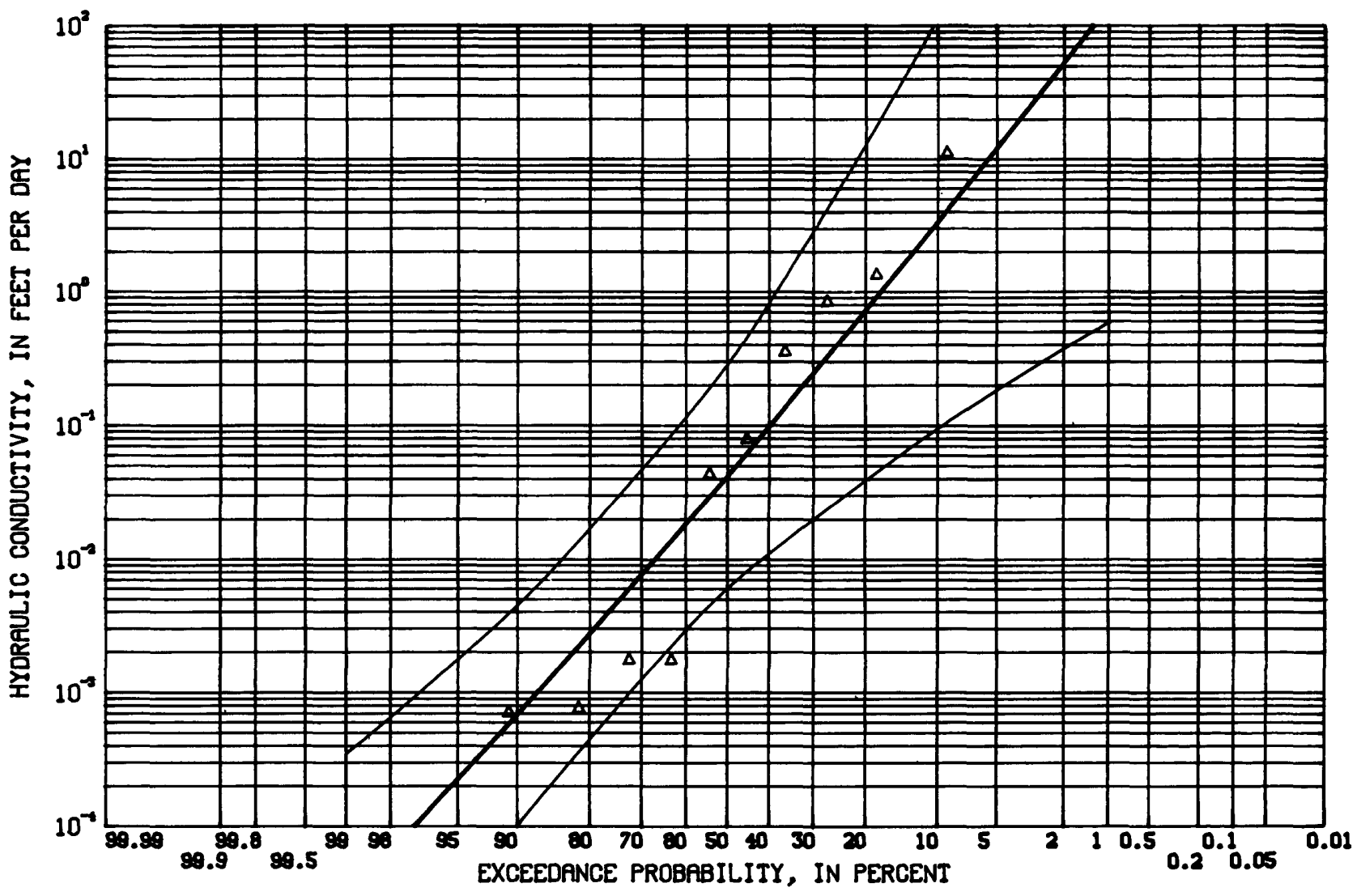

COPPER RIDGE DOLOMITE (REGOLITH AND BEDROCK) IN BEAR CREEK VALLEY

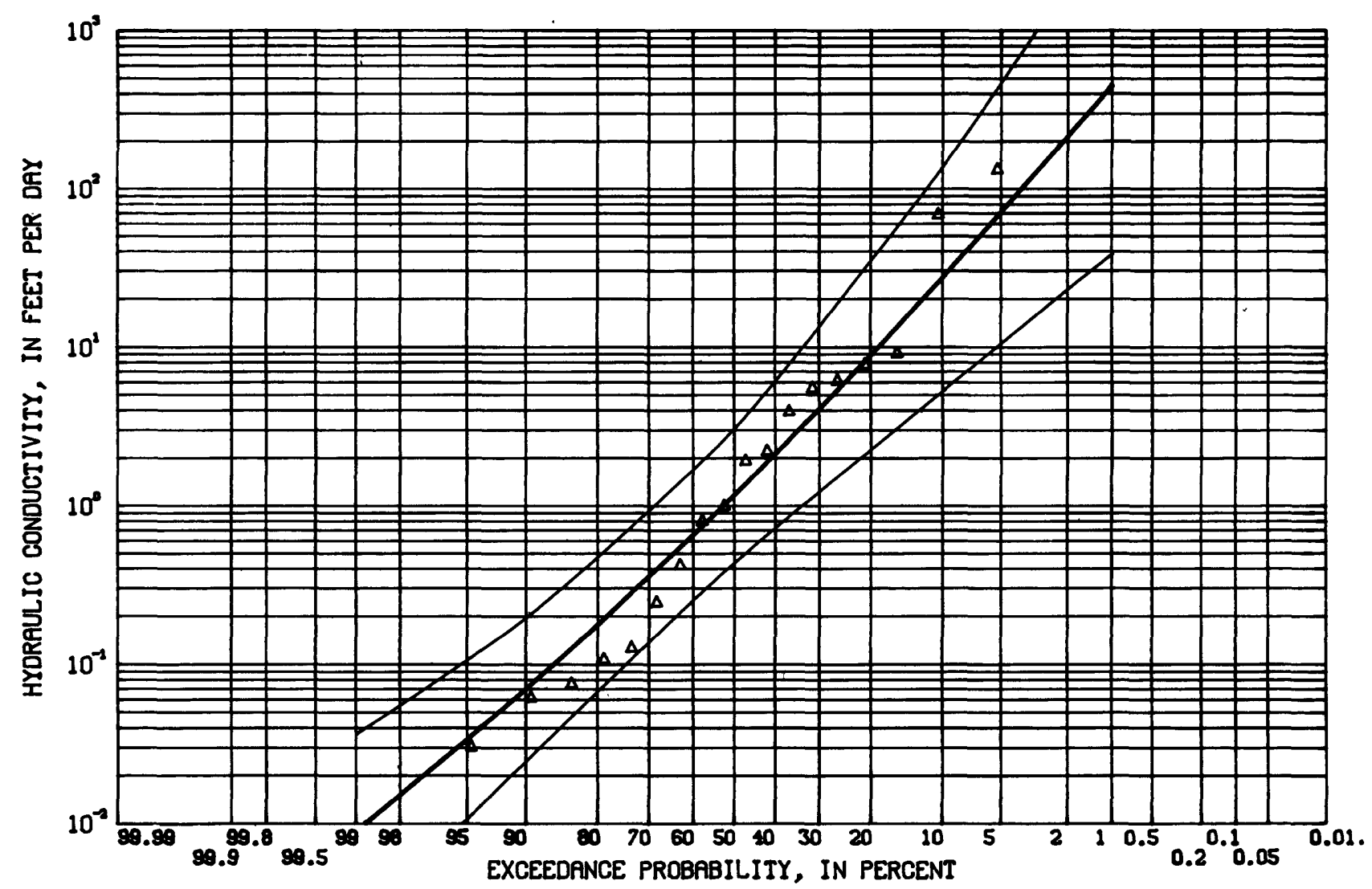

MAYNARDVILLE LIMESTONE (REGOLITH AND BEDROCK) IN BEAR CREEK VALLEY 


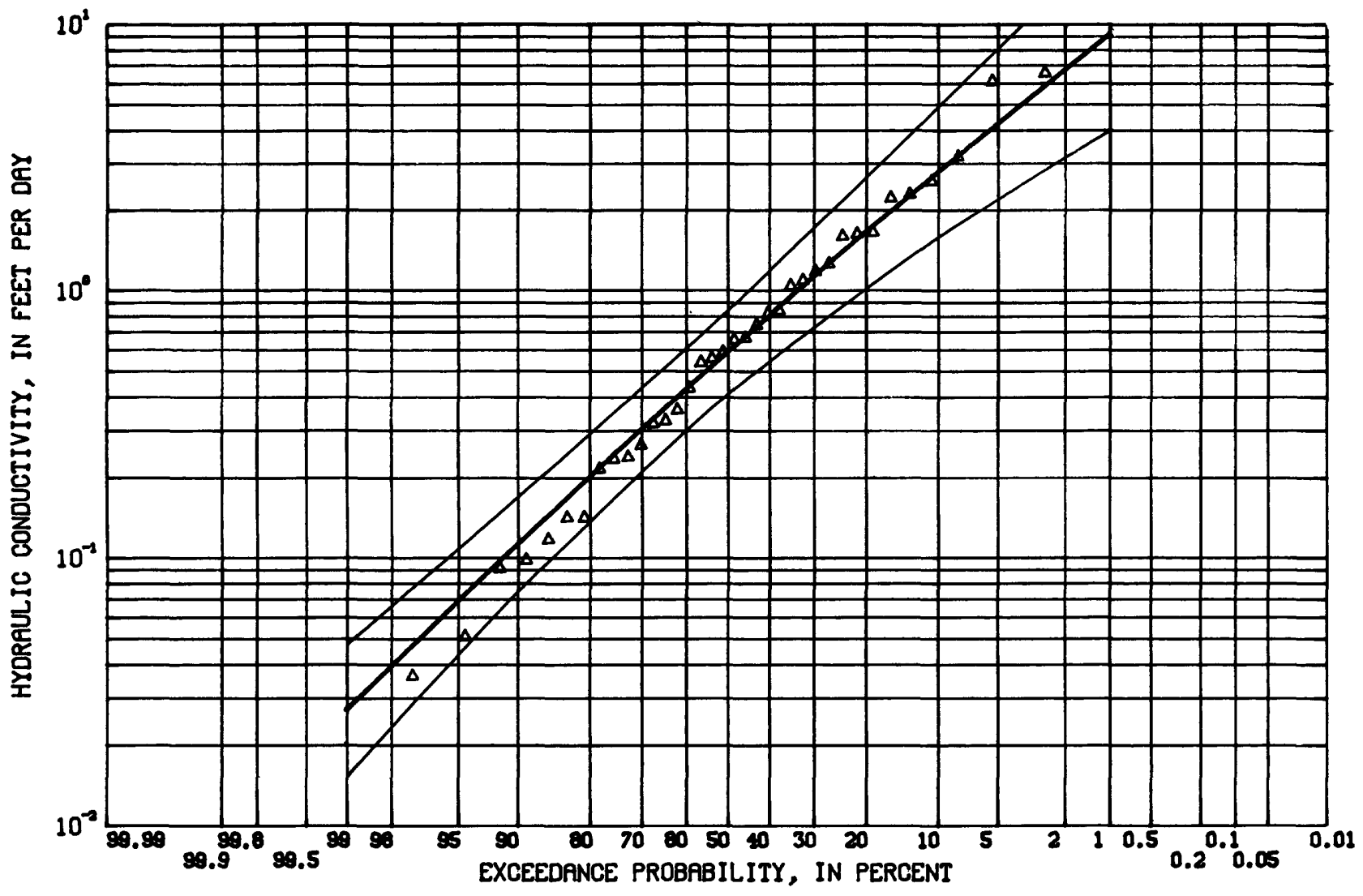

NOLICHUCKY SHALE (REGOLITH) IN BEAR CREEK AND MELTON VALLEYS

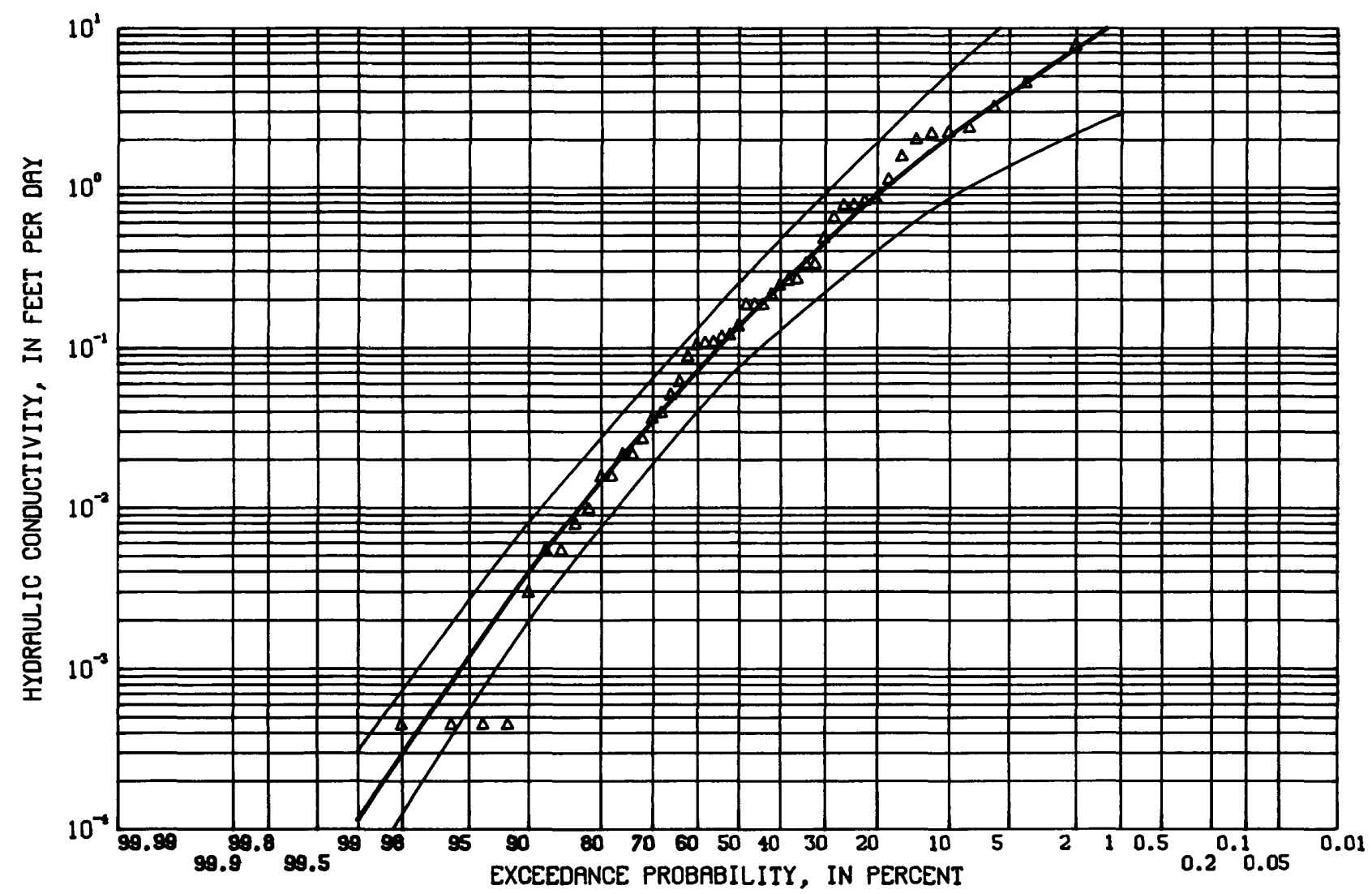

NOLICHUCKY SHALE (BEDROCK) IN BEAR CREEK AND MELTON VALLEYS 


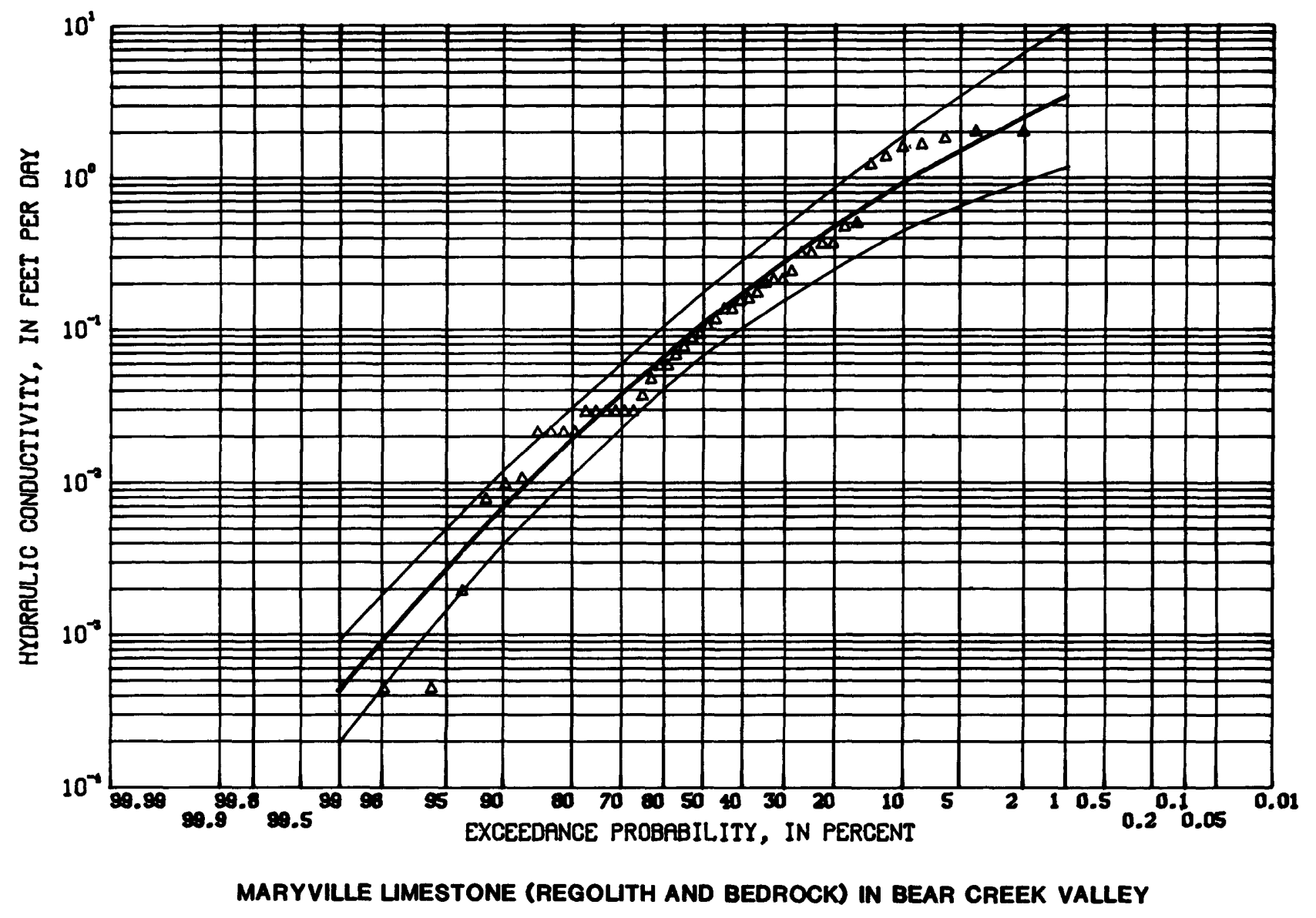




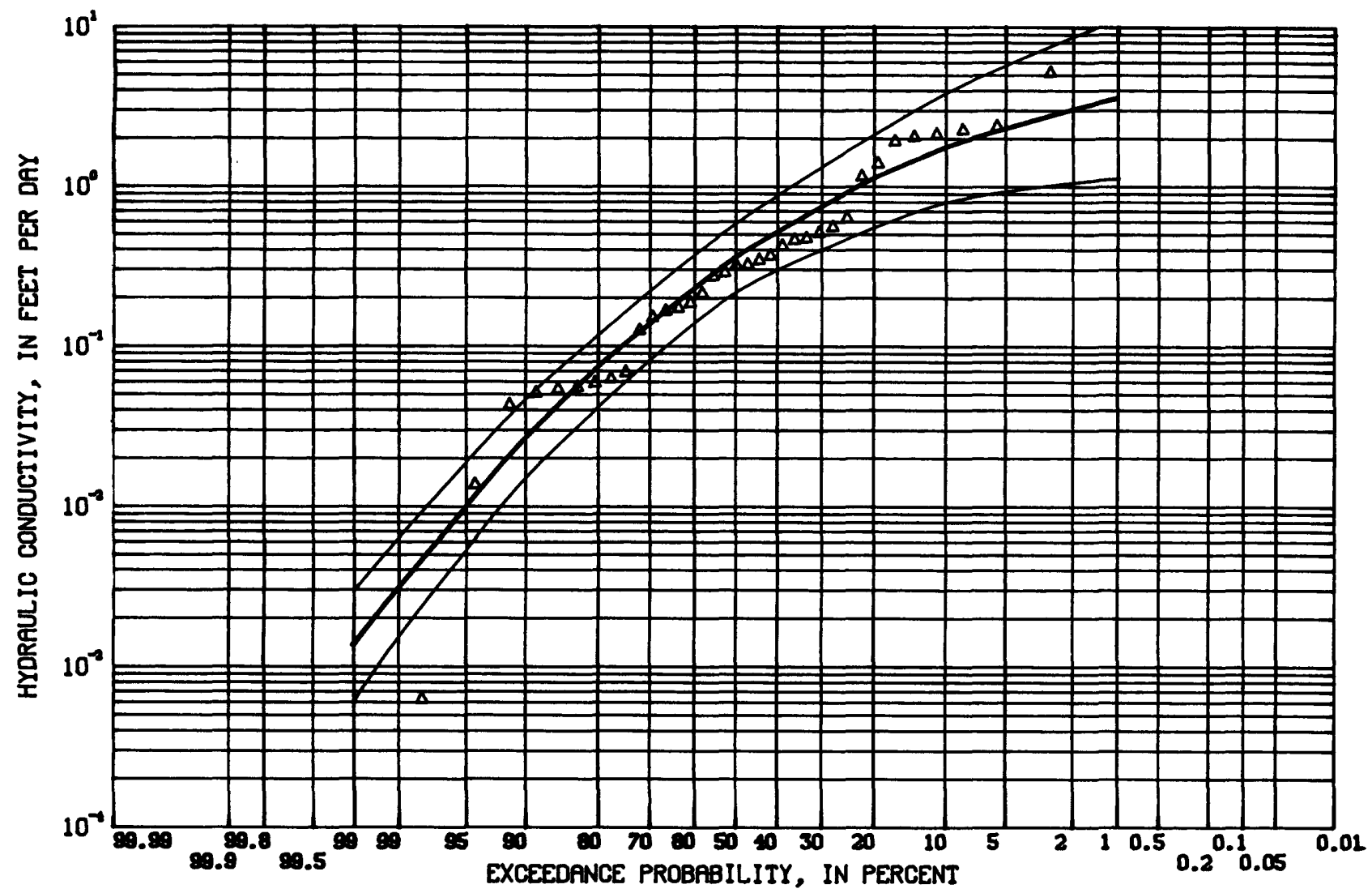

MARYVILLE LIMESTONE (REGOLITH) IN MELTON VALLEY

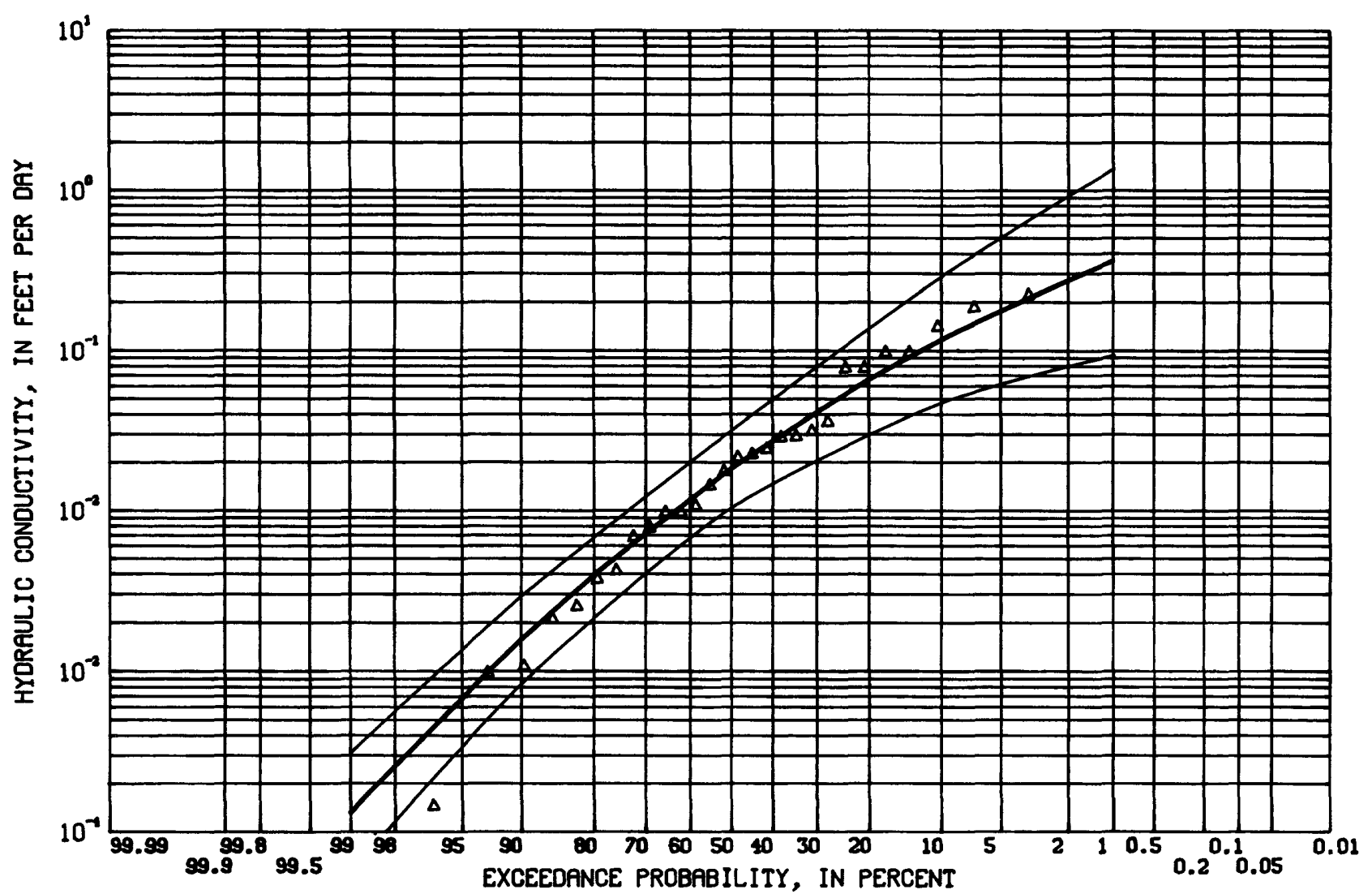

MARYVILLE LIMESTONE (BEDROCK) IN MELTON VALLEY 


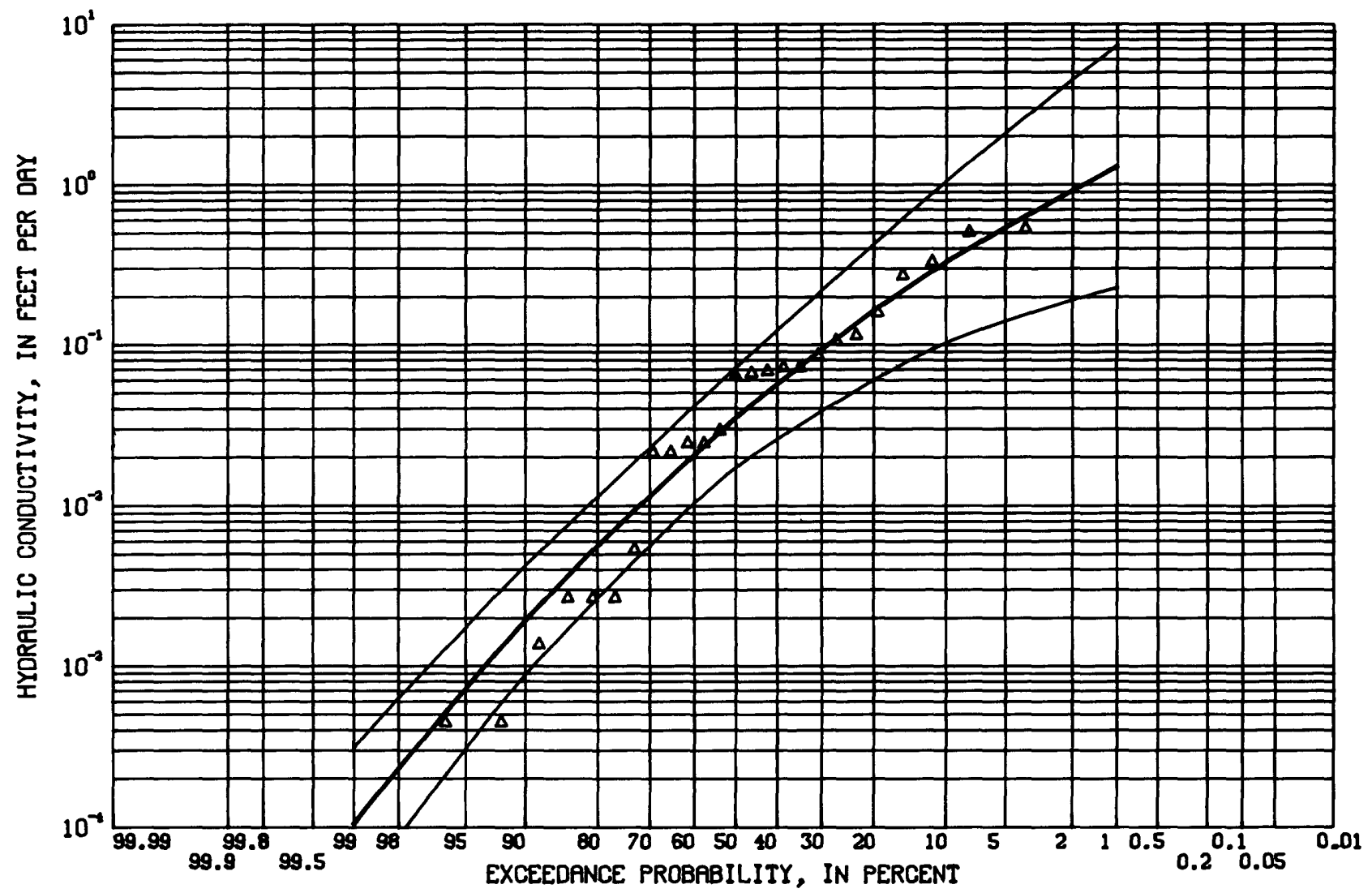

RUTLEDGE LIMESTONE AND ROGERSVILLE SHALE (REGOLITH AND BEDROCK) IN BEAR CREEK VALLEY

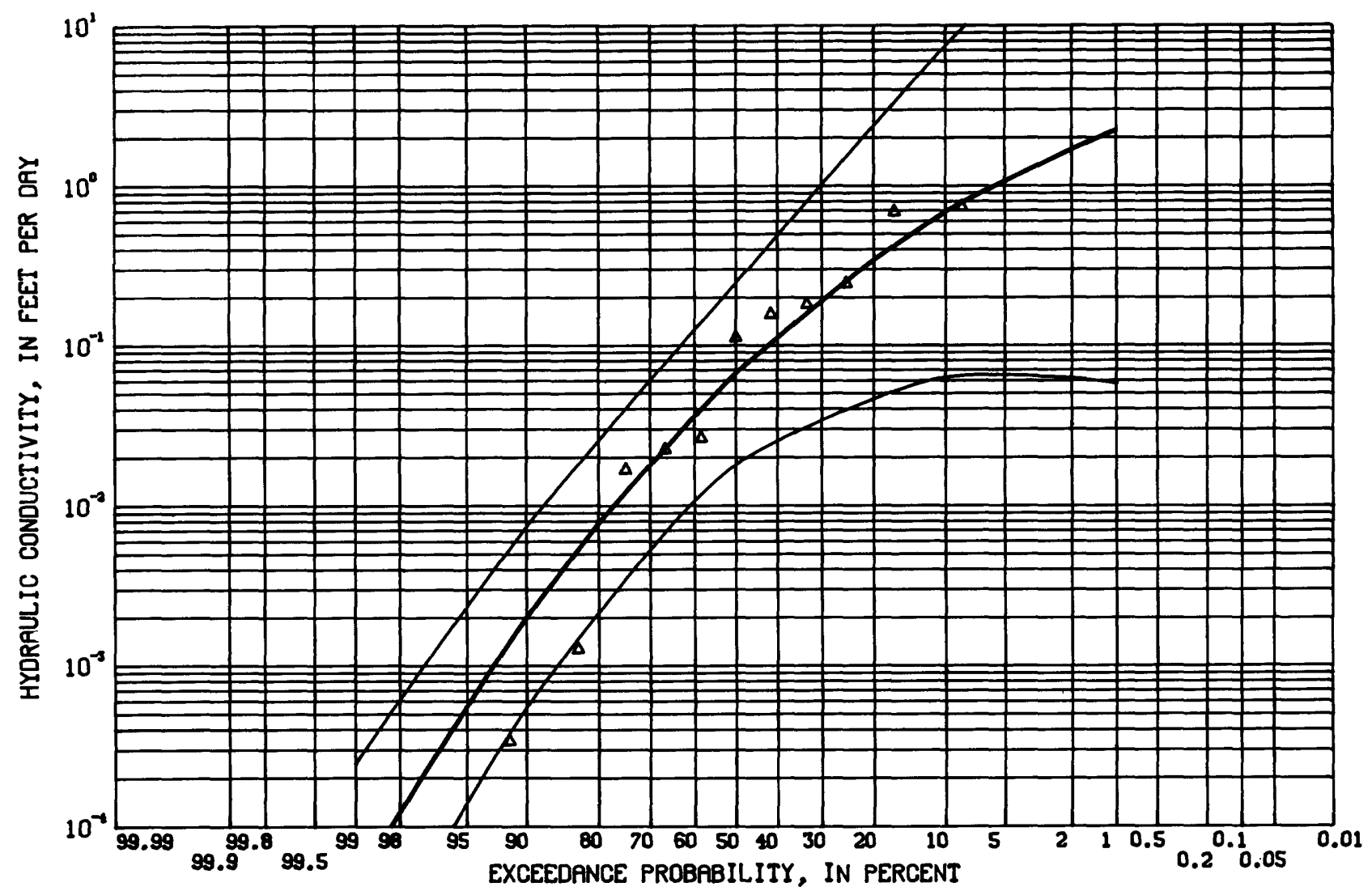

RUTLEDGE LIMESTONE AND ROGERSVILLE SHALE (REGOLITH AND BEDROCK) IN MELTON VALLEY 


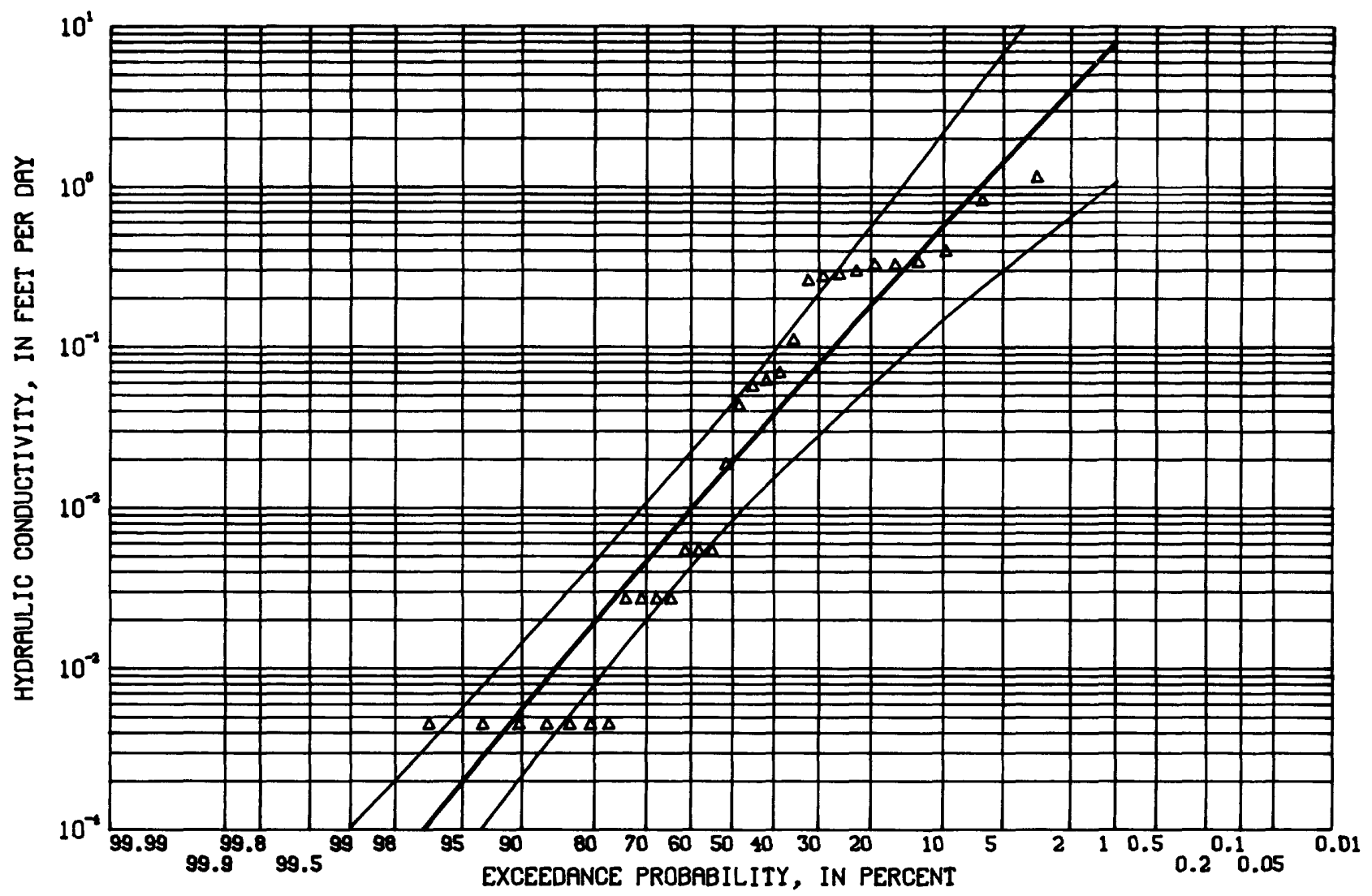

PUMPKIN VALLEY SHALE (REGOLITH AND BEDROCK) IN BEAR CREEK VALLEY

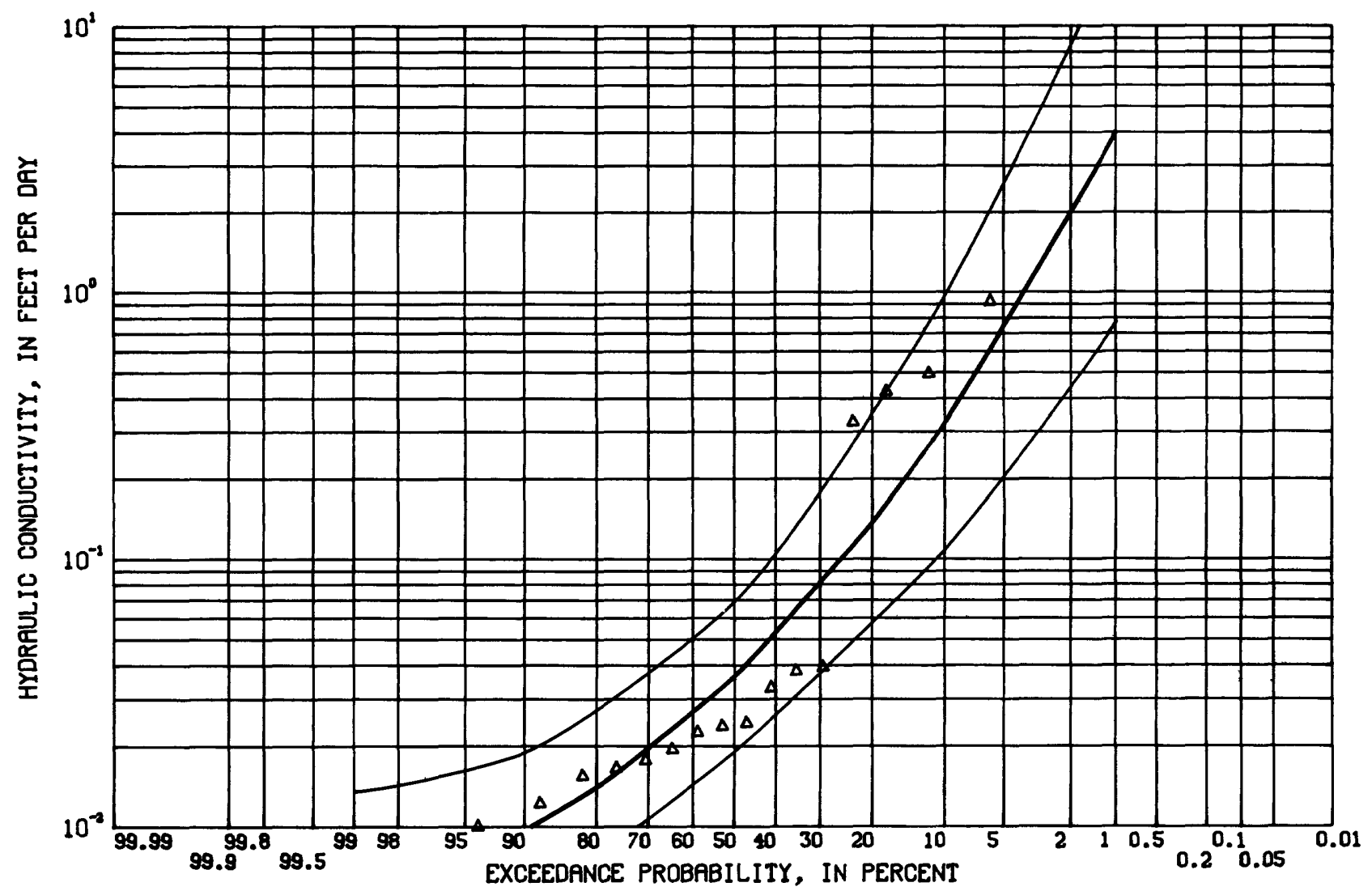

PUMPKIN VALLEY SHALE (REGOLITH) IN MELTON VALLEY 


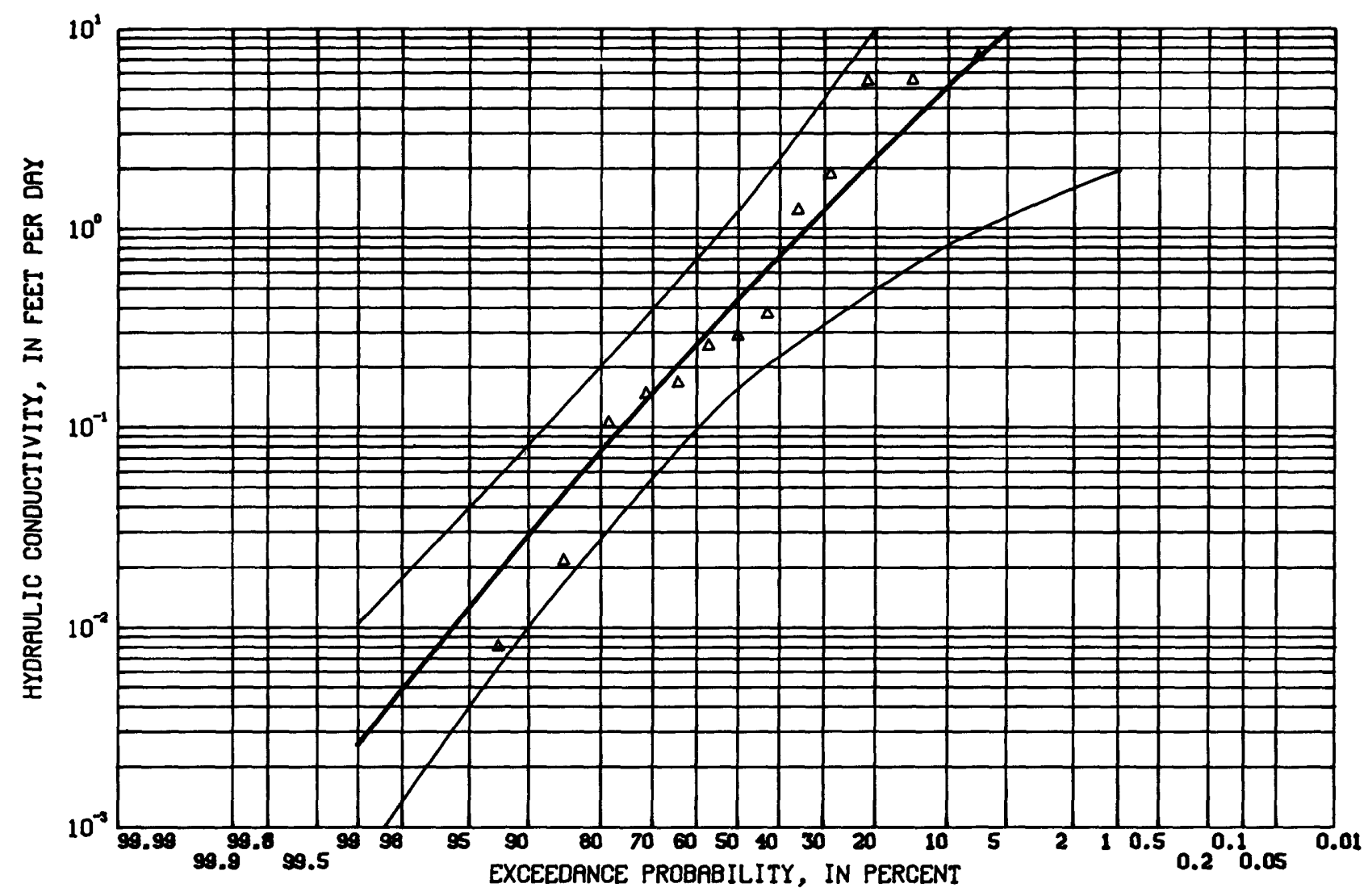

ROME FORMATION (BEDROCK IN BEAR CREEK VALLEY 